\title{
Stepwise Deoxygenation of Nitrite as a Pathway Affording Two Families of Ruthenium Corroles: Group 8 Periodic Trends and Relativistic Effects
}

\author{
Abraham B. Alemayehu, ${ }^{\text {a }}$ Hugo Vazquez-Lima, ${ }^{a}$ Kevin J. Gagnon, ${ }^{\mathrm{b}}$ and Abhik Ghosh;*,a \\ Department of Chemistry and Center for Theoretical and Computational Chemistry, \\ UiT - The Arctic University of Norway, N-9037 Troms $\varnothing$, Norway; \\ Email: abhik.ghosh@uit.no; Telephone: +47 45476145 \\ ${ }^{b}$ Advanced Light Source, Lawrence Berkeley National Laboratory, \\ Berkeley, CA 94720-8229, USA
}

\begin{abstract}
Given the many applications of ruthenium porphyrins, the rarity of ruthenium corroles and the underdeveloped state of their chemistry are clearly indicative of an area ripe for significant breakthroughs. The tendency of Ru corroles to form unreactive metal-metal bonded dimers has been recgnized as a key impediment in this area. Herein, by exposing free-base mesotris $\left(p\right.$-X-phenyl)corroles, $\mathrm{H}_{3}[\mathrm{~T} p \mathrm{XPC}]\left(\mathrm{X}=\mathrm{CF}_{3}, \mathrm{H}, \mathrm{Me}\right.$, and $\left.\mathrm{OMe}\right)$ and $\left[\mathrm{Ru}(\mathrm{COD}) \mathrm{Cl}_{2}\right]_{\mathrm{x}}$ in refluxing 2-methoxyethanol to nitrite, we have been able to reliably intercept the series $\mathrm{Ru}[\mathrm{T} p \mathrm{XPC}](\mathrm{NO})$ in a matter of seconds to minutes and subsequently $\mathrm{Ru}^{\mathrm{VI}}[\mathrm{T} p \mathrm{XPC}](\mathrm{N})$, the products of a second deoxygenation, over some 16 hours. Two of the $\mathrm{Ru}^{\mathrm{VI}} \mathrm{N}$ complexes and one $\mathrm{Ru}$-corrole dimer could be crystallographically analyzed; the $\mathrm{Ru}-\mathrm{N}_{\text {nitrido }}$ distances were found to be $\sim 1.61 \AA$, consistent with the triple-bonded character of the $\mathrm{Ru}^{\mathrm{VI}} \mathrm{N}$ units and essentially identical to Os- $\mathrm{N}_{\text {nitrido }}$ distances in analogous Os corroles. Spectroscopic and DFT calculations suggest that the RuNO corroles are best viewed as innocent $\{\mathrm{RuNO}\}^{6}$ complexes, whereas the analogous FeNO corroles are noninnocent, i.e., best viewed as $\{\mathrm{FeNO}\}^{7}$-corrole ${ }^{\cdot 2-}$. Both $\mathrm{Ru}^{\mathrm{VI}} \mathrm{N}$ and $\mathrm{Os}^{\mathrm{VI}} \mathrm{N}$ corroles exhibit sharp Soret bands, suggestive of an innocent macrocycle. A key difference between the two metals is that the Soret maxima of the $\mathrm{Os}^{\mathrm{VI}} \mathrm{N}$ corroles are some 25 $\mathrm{nm}$ redshifted relative to those of the $\mathrm{Ru}^{\mathrm{VI}} \mathrm{N}$ complexes. Careful TDDFT studies indicate that this difference is largely attributable to relativistic effects in $\mathrm{Os}^{\mathrm{VI}} \mathrm{N}$ corroles. The availability of two new classes of mononuclear Ru corroles potentially opens the door to new applications, in such areas as catalysis and cancer therapy.
\end{abstract}

Note: The crystal structures described in this paper have been deposited at the Cambridge Crystallographic Data Centre and been assigned the following deposition numbers: CCDC 1532043-1532045. 
Introduction. In the short space of 15-20 years, corroles, ring-contracted analogues of porphyrins, have progressed from being relative curiosities ${ }^{1}$ to a major class of ligands..$^{2,3,4}$ Today, it is no exaggeration to say that both the coordination chemistry and medicinal and other applications of corroles ${ }^{5}$ rival those of porphyrins. ${ }^{6,7}$ In recent years, we have focused on developing the coordination chemistry of $5 \mathrm{~d}$ transition metals with corroles. ${ }^{4,8}$ Many of these unusual size-mismatched complexes, which incorporate a large $5 \mathrm{~d}$ metal within a sterically constrained corrole ligand, exhibit fascinating photophysical properties such as NIR phosphorescence, triplet-triplet upconversion, and potential applications in oxygen sensing and photodynamic therapy. ${ }^{9,10,11}$ Interestingly, significant gaps remain in our knowledge of $4 \mathrm{~d}$ metallocorroles. Thus, niobium and palladium corroles are essentially unknown, while synthetic routes to mononuclear ruthenium corroles remain poorly developed. ${ }^{12}$ Herein, we report a modification of a literature synthesis, involving in situ trapping of mononuclear Ru corroles with nitrite, which provides a relatively general route to RuNO corroles. ${ }^{13}$ Importantly, we found that RuNO corroles undergo thermally induced deoxygenation to yield $\mathrm{Ru}^{\mathrm{VI}} \mathrm{N}$ corroles, the first $\mathrm{Ru}(\mathrm{VI})$ derivatives of corroles (Figure 1). These findings significantly expand the scope of $\mathrm{Ru}-$ corrole chemistry and also provide a wealth of insights into Group 8 periodic trends and relativistic effects, ${ }^{14}$ as described below.

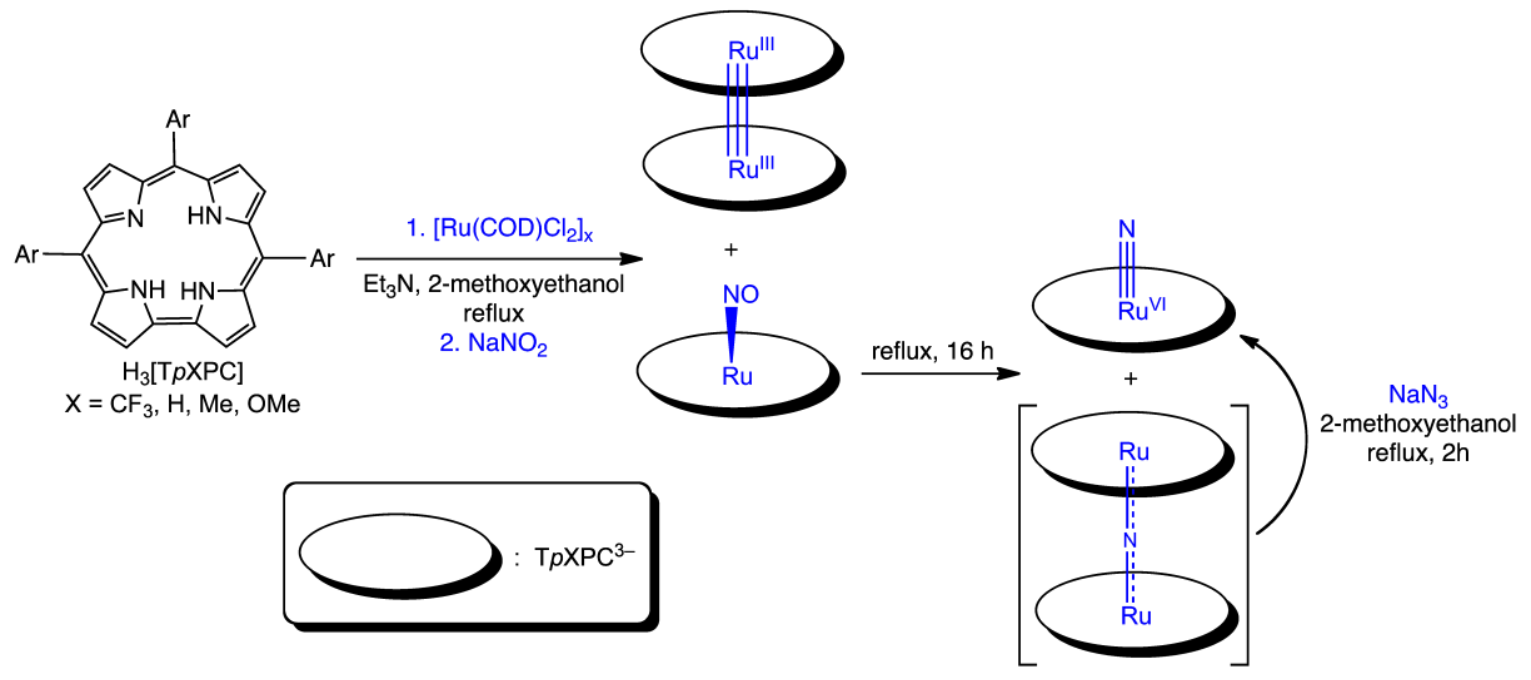

Figure 1. Synthetic routes to Ru meso-triarylcorroles. 


\section{Results and discussion. (a) Synthetic routes to RuNO and $\mathbf{R u}^{\mathrm{VI}} \mathbf{N}$ corroles. The} synthesis of $\mathrm{Ru}$ corroles is illustrative of the general challenges involved in the synthesis of $4 \mathrm{~d}$ and $5 \mathrm{~d}$ metallocorroles. The fact that these syntheses typically require highly specific reaction conditions, in terms of reagent, solvent, and temperature, can probably be attributed to the sizemismatched nature of the complexes. ${ }^{15,16,17,18,19}$ Another potential problem is that certain of the metals are prone to metal-metal bonding ${ }^{20,21}$ and thus to yield metal-metal-bonded metallocorrole dimers. ${ }^{22,23}$ Thus, unless special care is taken, the interaction of free-base corroles with $\left[\mathrm{Ru}(\mathrm{COD}) \mathrm{Cl}_{2}\right]_{\mathrm{x}}(\mathrm{x} \geq 2)$ in refluxing 2-methoxyethanol (with triethyamine as a quencher for the $\mathrm{HCl}$ produced in the reaction) yields rather chemically inert $\mathrm{Ru}$-corrole dimers of the form $[\mathrm{Ru}(\mathrm{Cor})]_{2 .}{ }^{22,23} \mathrm{By}$ trapping putative monomeric $\mathrm{Ru}$-corrole species in the reaction mixture with NO, Gross and coworkers managed to isolate two different RuNO corroles. ${ }^{12}$ In this study, we chose nitrite as the nitrosylating agent and, by adding saturated aqueous $\mathrm{NaNO}_{2}$ within 30-60 seconds of adding $\left[\mathrm{Ru}(\mathrm{COD}) \mathrm{Cl}_{2}\right]_{\mathrm{x}}$, we successfully isolated a series of RuNO corroles, $\mathrm{Ru}[\mathrm{T} p \mathrm{XPC}](\mathrm{NO})$, where $\mathrm{T} \mathrm{XPC}^{3-}$ is the trianion of meso-tris $\left(p-\mathrm{X}\right.$-phenyl)corrole and $\mathrm{X}=\mathrm{CF}_{3}$, $\mathrm{H}, \mathrm{Me}$, and $\mathrm{OMe}$.

The synthesis of $\mathrm{Ru}^{\mathrm{VI}} \mathrm{N}$ corroles came about in a more indirect and serendipitous manner. A protocol analogous to that used for $\mathrm{Os}^{\mathrm{VI}} \mathrm{N}$ corroles, ${ }^{24}$ employing $\mathrm{Ru}_{3}(\mathrm{CO})_{12}$ and $\mathrm{NaN}_{3}$, did not yield the desired $\mathrm{Ru}^{\mathrm{VI}} \mathrm{N}$ corroles. Use of $\left[\mathrm{Ru}(\mathrm{COD}) \mathrm{Cl}_{2}\right]_{\mathrm{x}}$ and $\mathrm{NaN}_{3}$ in 2-methoxyethanol also failed to give the desired products. An attempt to optimize the above synthesis of RuNO corroles, where the reaction mixture was heated for $2 \mathrm{~h}$ (instead of seconds to minutes), led to a fortunate breakthrough. Column chromatographic purification of the reaction mixture led to an unexpected greenish brown fraction with a sharp Soret band with $\lambda_{\max }$ at $417 \mathrm{~nm}$ that was visibly different from wine-red solutions of $\mathrm{Ru}[\mathrm{T} p \mathrm{XPC}](\mathrm{NO})$. Electrospray ionization mass spectrometry (ESI-MS) indicated a molecular weight consistent with an $\mathrm{Ru}^{\mathrm{VI}} \mathrm{N}$ formulation, which was also supported by ${ }^{1} \mathrm{H}$ NMR spectroscopy. Further experimentation showed that heating the reaction mixture for $16 \mathrm{~h}$ resulted in full deoxygenation of the $\mathrm{Ru}[\mathrm{T} p \mathrm{XPC}](\mathrm{NO})$ derivatives to $\mathrm{Ru}^{\mathrm{VI}}[\mathrm{T} p \mathrm{XPC}](\mathrm{N})$. Interestingly, these reaction conditions also led to another minor product, which was isolated with some difficulty via elution with $5 \% \mathrm{MeOH}$ in dichloromethane from a basic alumina column. ESI-MS suggested a $\mu$-nitrido formulation, $\{\operatorname{Ru}[\mathrm{T} p \mathrm{XPC}]\}_{2}(\mu$-N), for this complex; full characterization of these species, however, was not carried out as part of this study. Interestingly, upon refluxing with $\mathrm{NaN}_{3}$ in 2-methoxyethanol for $2 \mathrm{~h}$, the putative $\mu$ nitrido complexes underwent full conversion to the terminal nitrides, $\mathrm{Ru}^{\mathrm{VI}}[\mathrm{T} p \mathrm{XPC}](\mathrm{N})$. 
Stepwise deoxygenation of nitrite thus has afforded simple, one-pot routes to two new series of Ru corroles, $\mathrm{Ru}[\mathrm{T} p \mathrm{XPC}](\mathrm{NO})$ and $\mathrm{Ru}^{\mathrm{VI}}[\mathrm{T} p \mathrm{XPC}](\mathrm{N})$. Both deoxygenations are relatively well precedented. ${ }^{25,26}$ In particular, Ru(III)-EDTA complexes have been recently shown to effect oxygen atom transfer from nitrite. ${ }^{27}$ Nitrosyl cleavage to yield nitride complexes is rarer, but still, several examples are known. ${ }^{28,29} \mathrm{~A}$ key gap in our knowledge centers around the identity of the oxygen atom acceptor in these reactions. The fact that the syntheses also work well with $\left[\mathrm{Ru}(p \text {-cymene }) \mathrm{I}_{2}\right]_{2}$ as the $\mathrm{Ru}$ source suggests that $\mathrm{COD}$ is not the key oxygen acceptor. On the other hand, both nitrite and 2-methoxyethanol are expected to be competent oxygen atom scavengers, even though we have not yet confirmed oxygen atom transfer to these species.

(b) Proof of composition and structure. Clean thin-layer chromatograms, ESI-MS, fully assigned diamagnetic ${ }^{1} \mathrm{H}$ NMR spectra, single-crystal X-ray structures (in some cases), and IR spectra (showing clear $v_{\mathrm{NO}}$ 's) provided convincing proof of the composition of the various $\mathrm{Ru}[\mathrm{T} p \mathrm{XPC}](\mathrm{NO}),\{\mathrm{Ru}[\mathrm{T} p \mathrm{XPC}]\}_{2}$, and $\mathrm{Ru}^{\mathrm{VI}}[\mathrm{T} p \mathrm{XPC}](\mathrm{N})$ complexes isolated. In general, fast meso-aryl rotation at room temperature results in broad ${ }^{1} \mathrm{H} \mathrm{NMR}$ signals for the ortho and meta aryl protons for the great majority of the complexes. Lowering the temperature to $253 \mathrm{~K}$ led to well-resolved, fully assignable ${ }^{1} \mathrm{H}$ NMR spectra, as illustrated by key examples in Figures 2 and 3. An interesting observation from Figure 2 is that both the $\beta$ and aryl protons of $\mathrm{Ru}^{\mathrm{VI}}[\mathrm{T} p \mathrm{XPC}](\mathrm{N})$ are systematically deshielded relative to those of $\mathrm{Ru}[\mathrm{T} p \mathrm{XPC}](\mathrm{NO})$; the $\beta$ protons of the nitrido series are some $0.4 \mathrm{ppm}$ deshielded relative to those of the nitrosyl series. Two of the Ru-corrole dimers were isolated and fully characteried; for all three complexes, the ${ }^{1} \mathrm{H}$ NMR spectra indicated symmetry-related Ru-corrole fragments, each with $C_{\mathrm{s}}$ local symmetry, on the NMR timescale. Single-crystal X-ray structures could be obtained for two of the nitrido complexes, $\mathrm{Ru}^{\mathrm{VI}}[\mathrm{TPC}](\mathrm{N})$ and $\mathrm{Ru}^{\mathrm{VI}}\left[\mathrm{T} p \mathrm{CF}_{3} \mathrm{PC}\right](\mathrm{N})$, and for $\left\{\mathrm{Ru}\left[\mathrm{T} p \mathrm{CF}_{3} \mathrm{PC}\right]\right\}_{2}$ (Tables 1 and 2 and Figure 4). In each structure, the $\mathrm{Ru}$ is displaced 0.5-0.6 ̊ relative to the mean plane of the corrole nitrogens. For the two nitrido structures, the $\mathrm{Ru}-\mathrm{N}$ distances involving the nitrido nitrogens are each $1.614 \pm 0.001 \AA$, consistent with triple-bonded $\mathrm{Ru}^{\mathrm{VI}} \mathrm{N}$ units. Not surprisingly, the geometry parameters of the $\mathrm{Ru}^{\mathrm{VI}} \mathrm{N}$ complexes are also very similar to those of previously reported $\mathrm{Os}^{\mathrm{VI}} \mathrm{N}$ corroles. 


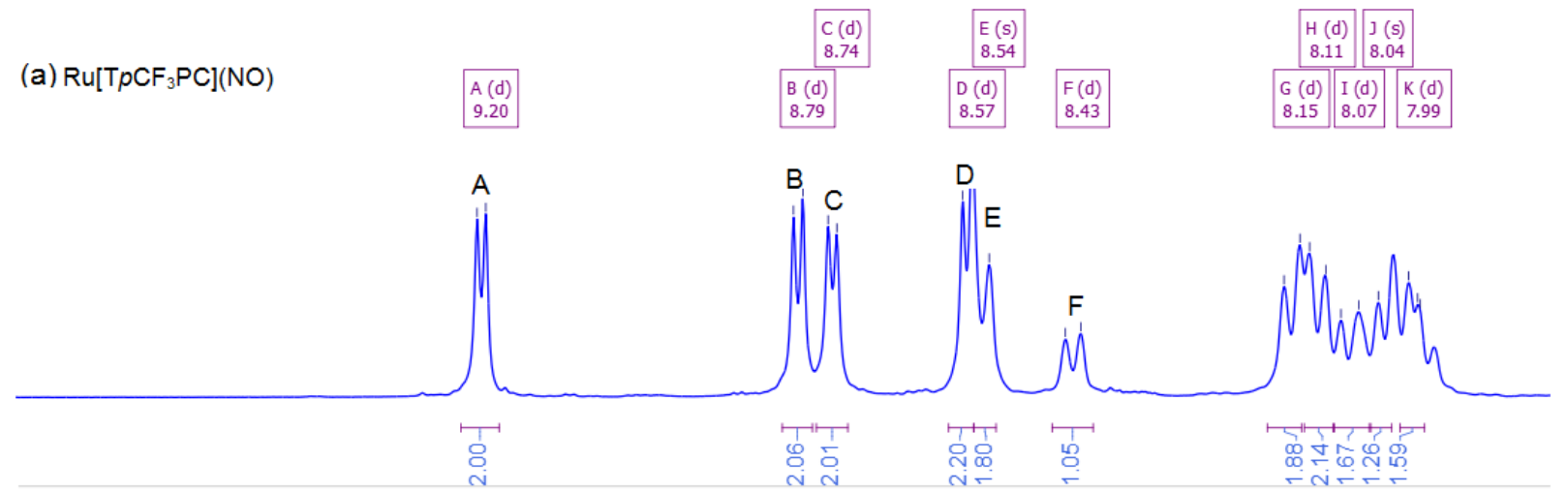

(b) Ru[TpCF $3 \mathrm{PC}](\mathrm{N})$

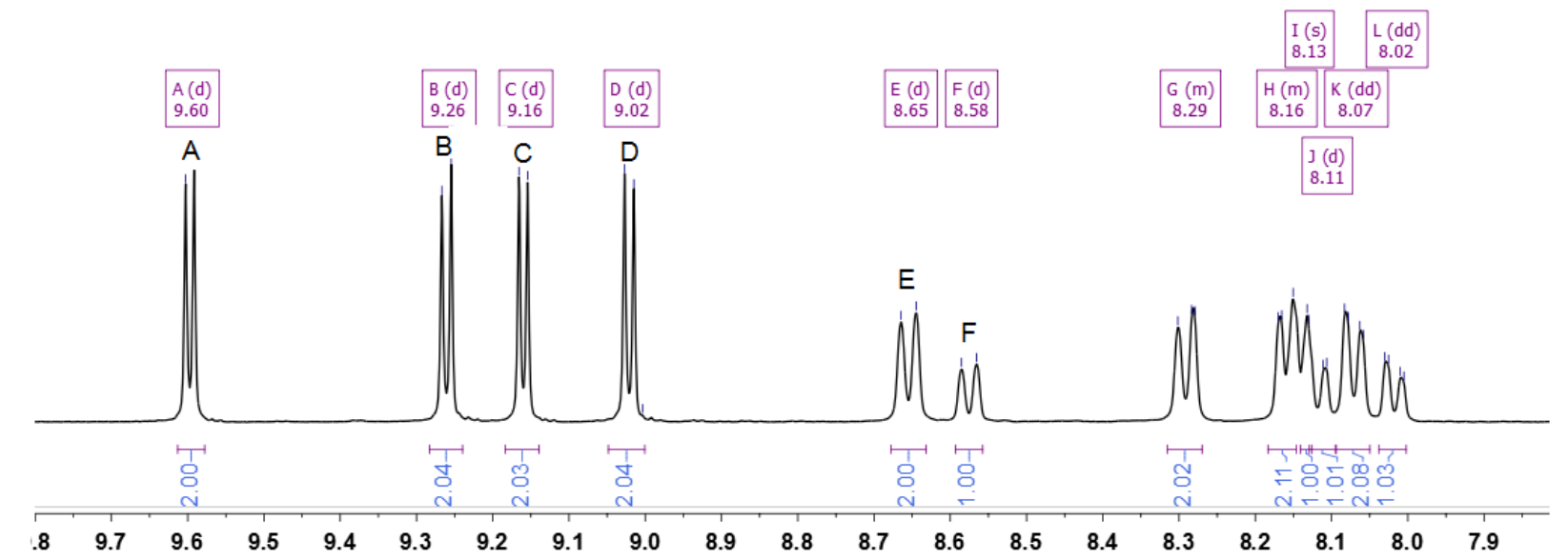

Figure 2. ${ }^{1} \mathrm{H}$ NMR spectra $\left(253 \mathrm{~K}, \mathrm{CD}_{2} \mathrm{Cl}_{2}\right.$ ) of $\mathrm{Ru}\left[\mathrm{T} p \mathrm{CF}_{3} \mathrm{PC}\right](\mathrm{NO})$ (top) and $\mathrm{Ru}\left[\mathrm{T} p \mathrm{CF}_{3} \mathrm{PC}\right](\mathrm{N})$ (bottom). A, B, C and D: $\beta$-H; E: 5,15-o1-Ph; F: 10-o1-Ph. (The notation $o 1, o 2$ and $m 1, m 2$ refer to diastereotopic ortho and meta protons, respectively.)

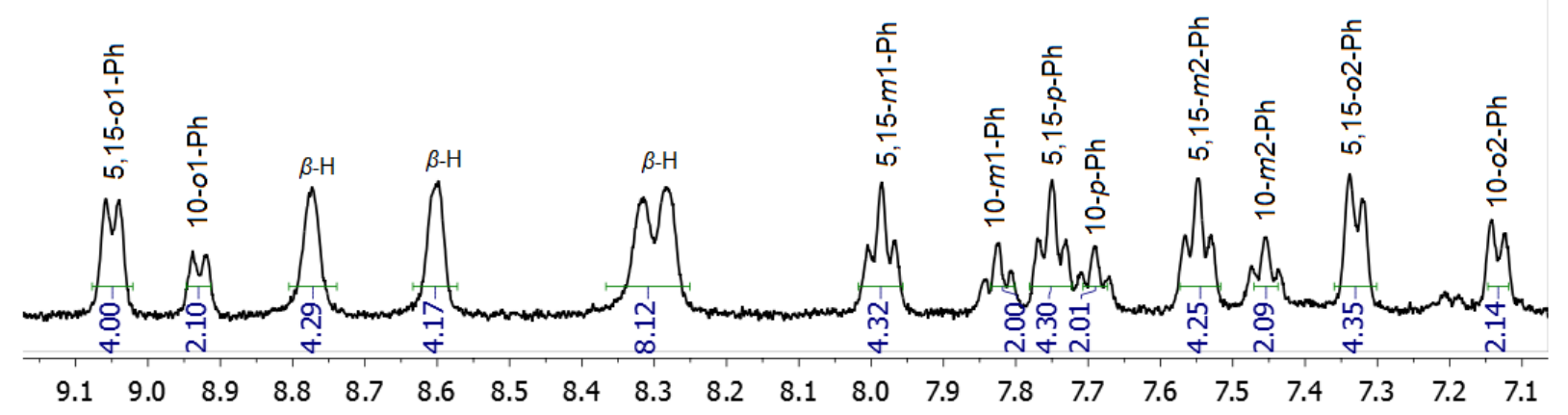

Figure 3. ${ }^{1} \mathrm{H}$ NMR spectrum $\left(253 \mathrm{~K}, \mathrm{CD}_{2} \mathrm{Cl}_{2}\right)$ of $\{\mathrm{Ru}[\mathrm{TPC}]\}_{2}$. 
Table 1. Crystallographic data for $\mathrm{Ru}^{\mathrm{VI}}[\mathrm{TPC}](\mathrm{N}), \mathrm{Ru}^{\mathrm{VI}}\left[\mathrm{T} p \mathrm{CF}_{3} \mathrm{PC}\right](\mathrm{N})$, and $\left\{\mathrm{Ru}\left[\mathrm{T} p \mathrm{CF}_{3} \mathrm{PC}\right]\right\}_{2}$.

\begin{tabular}{|c|c|c|c|}
\hline Sample & $\mathrm{Ru}[\mathrm{TPC}](\mathrm{N})$ & $\mathrm{Ru}\left[\mathrm{T} p \mathrm{CF}_{3} \mathrm{PC}\right](\mathrm{N})$ & $\left\{\mathrm{Ru}\left[\mathrm{T} p \mathrm{CF}_{3} \mathrm{PC}\right]\right\}_{2}$ \\
\hline Chemical formula & $\mathrm{C}_{37} \mathrm{H}_{23} \mathrm{~N}_{5} \mathrm{Ru}$ & $\mathrm{C}_{40} \mathrm{H}_{20} \mathrm{~F}_{9} \mathrm{~N}_{5} \mathrm{Ru}$ & $\mathrm{C}_{80} \mathrm{H}_{40} \mathrm{~F}_{18} \mathrm{~N}_{8} \mathrm{Ru}_{2}$ \\
\hline Formula mass & 638.67 & 842.68 & 1657.34 \\
\hline Crystal system & Monoclinic & Monoclinic & Triclinic \\
\hline Space group & $P 2_{1} / c$ & $P 2_{1} / c$ & $P \square$, \\
\hline$\lambda(\AA)$ & 0.7749 & 0.7749 & 0.7749 \\
\hline$a(\AA)$ & $12.1216(5)$ & $16.390(12)$ & $9.7575(5)$ \\
\hline$b(\AA)$ & $22.0370(9)$ & $14.048(11)$ & $15.2026(8)$ \\
\hline$c(\AA)$ & $10.7799(5)$ & $14.056(11)$ & $16.0513(8)$ \\
\hline$\alpha$ (deg.) & 90 & 90 & $111.527(3)$ \\
\hline$\beta$ (deg.) & $100.249(2)$ & $93.640(9)$ & $96.307(3)$ \\
\hline$\gamma($ deg. $)$ & 90 & 90 & $101.899(3)$ \\
\hline Z & 4 & 4 & 1 \\
\hline $\mathrm{V}\left(\AA^{3}\right)$ & $2833.6(2)$ & $3230(4)$ & 2121.87(19) \\
\hline Temperature (K) & $100(2)$ & $100(2)$ & $100(2)$ \\
\hline Density $\left(\mathrm{g} / \mathrm{cm}^{3}\right)$ & 1.497 & 1.733 & 1.297 \\
\hline Measured reflections & 53000 & 13834 & 40450 \\
\hline Unique reflections & 10358 & 2734 & 16036 \\
\hline Parameters & 443 & 496 & 611 \\
\hline Restraints & 343 & 92 & 696 \\
\hline $\mathrm{R}_{\text {int }}$ & 0.0541 & 0.0949 & 0.0414 \\
\hline$\theta$ range (deg.) & $2.117-36.042$ & $2.237-21.225$ & $2.376-36.671$ \\
\hline $\mathrm{R}_{1}, \mathrm{wR}_{2}$ all data & $0.0438,0.1153$ & $0.0739,0.1775$ & $0.0659,0.1765$ \\
\hline $\mathrm{S}(\mathrm{GooF})$ all data & 1.025 & 1.086 & 1.066 \\
\hline Max/min res. dens. $\left(\mathrm{e} / \AA^{3}\right)$ & $1.667 /-1.498$ & $2.037 /-0.703$ & $2.828 /-1.615$ \\
\hline
\end{tabular}

Table 2. Selected crystallographic geometry parameters $(\AA)$ for $\mathrm{Ru}^{\mathrm{VI}}[\mathrm{TPC}](\mathrm{N})$, $\mathrm{Ru}^{\mathrm{VI}}\left[\mathrm{T} p \mathrm{CF}_{3} \mathrm{PC}\right](\mathrm{N})$, and $\left\{\mathrm{Ru}\left[\mathrm{T} p \mathrm{CF}_{3} \mathrm{PC}\right]\right\}_{2}$.

\begin{tabular}{ll|ll|ll}
\multicolumn{2}{c|}{$\mathrm{Ru}^{\mathrm{VI}}[\mathrm{TPC}](\mathrm{N})$} & \multicolumn{2}{|c|}{$\mathrm{Ru}^{\mathrm{VI}}\left[\mathrm{T} p \mathrm{CF}_{3} \mathrm{PC}\right](\mathrm{N})$} & \multicolumn{2}{|c}{$\mathrm{Ru}\left[\mathrm{T} p \mathrm{CF}_{3} \mathrm{PC}\right]_{2}$} \\
\hline $\mathrm{Ru}(1)-\mathrm{N}(1)$ & $1.9732(18)$ & $\mathrm{Ru}(1)-\mathrm{N}(1)$ & $1.917(9)$ & $\mathrm{Ru}(1)-\mathrm{N}(1)$ & $1.963(2)$ \\
$\mathrm{Ru}(1)-\mathrm{N}(2)$ & $1.994(2)$ & $\mathrm{Ru}(1)-\mathrm{N}(2)$ & $1.991(10)$ & $\mathrm{Ru}(1)-\mathrm{N}(2)$ & $1.983(2)$ \\
$\mathrm{Ru}(1)-\mathrm{N}(3)$ & $2.0009(19)$ & $\mathrm{Ru}(1)-\mathrm{N}(3)$ & $1.921(9)$ & $\mathrm{Ru}(1)-\mathrm{N}(3)$ & $1.980(2)$ \\
$\mathrm{Ru}(1)-\mathrm{N}(4)$ & $1.9654(19)$ & $\mathrm{Ru}(1)-\mathrm{N}(4)$ & $1.966(11)$ & $\mathrm{Ru}(1)-\mathrm{N}(4)$ & $1.963(2)$ \\
$\mathrm{Ru}(1)-\mathrm{N}(5)$ & $1.613(2)$ & $\mathrm{Ru}(1)-\mathrm{N}(5)$ & $1.615(10)$ & $\mathrm{Ru}(1)-\mathrm{Ru}(1)^{\mathrm{a}}$ & $2.1827(5)$ \\
$\mathrm{Ru}(\mathrm{I})-4 \mathrm{~N}_{\text {plane }}$ & $0.605(1)$ & $\mathrm{Ru}(\mathrm{I})-4 \mathrm{~N}_{\text {plane }}$ & $0.558(5)$ & $\mathrm{Ru}(\mathrm{I})-4 \mathrm{~N}_{\text {plane }}$ & $0.5171(15)$ \\
\hline \multicolumn{3}{c}{${ }^{\mathrm{a}}{ }_{-\mathrm{x}+1,-\mathrm{y}+1,-\mathrm{z}+1}$}
\end{tabular}


(a)

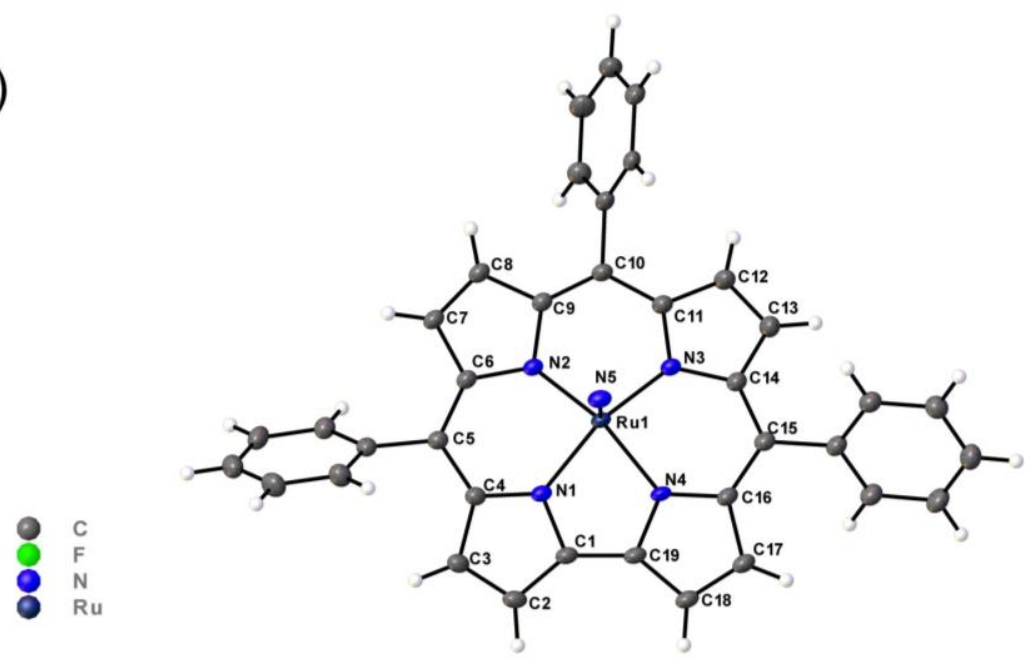

(b)

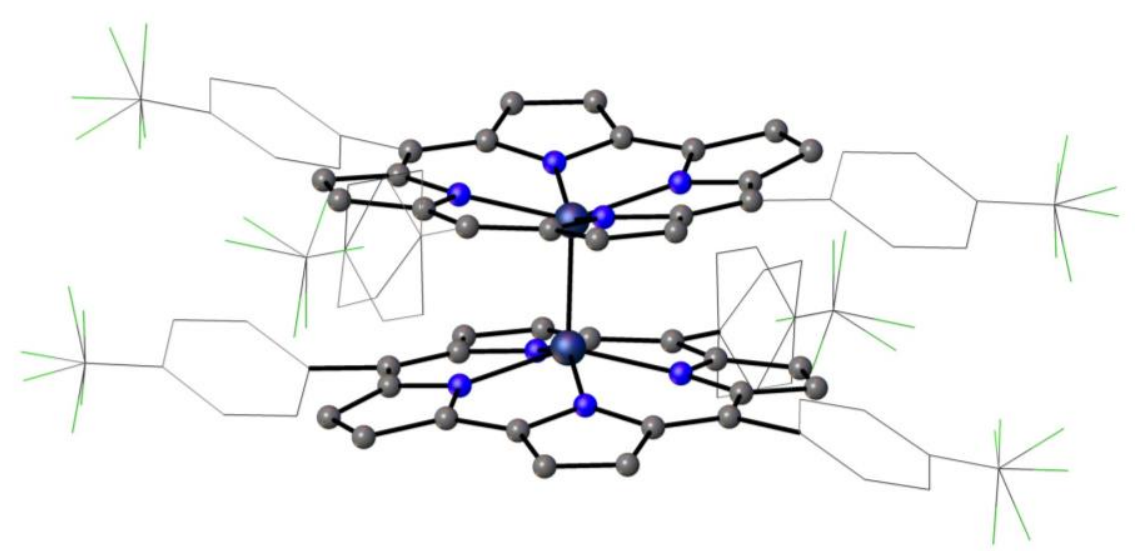

Figure 4. X-ray structures of (a) $\mathrm{Ru}^{\mathrm{VI}}[\mathrm{TPC}](\mathrm{N})$ and (b) $\left\{\mathrm{Ru}\left[\mathrm{T} p \mathrm{CF}_{3} \mathrm{PC}\right]\right\}_{2}$.

(c) Electronic-structural aspects of RuNO corroles. ${ }^{30,31}$ Several lines of evidence have recently led us to reformulate FeNO corroles, long regarded as genuine $\{\mathrm{FeNO}\}^{6}$ complexes, as spin-coupled $\{\mathrm{FeNO}\}^{7}$-corrole $^{\cdot 2-}$ species $^{32,33,34}$ It was thus of considerable interest to determine whether such a noninnocent description might also apply to RuNO corroles. For paramagnetic metallocorroles or those with thermally accessible paramagnetic excited states (such as simple $\mathrm{Cu}$ corroles), ${ }^{1} \mathrm{H} \mathrm{NMR}^{35,36}$ or EPR ${ }^{19}$ spectroscopy can often address the question of innocence or noninnocence of the corrole macrocycle. For diamagnetic, spin-coupled metallocorroles, more indirect probes are generally required. The fact the infrared $v_{\text {NO's }}$ of the RuNO corroles (1727$1740 \mathrm{~cm}^{-1}$, Table 3 ) are somewhat lower than those of six-coordinate $\{\mathrm{RuNO}\}^{6}$ porphyrins (typically $\left.>1800 \mathrm{~cm}^{-1}\right)^{37,38,39}$ might appear to suggest a degree of $\{\mathrm{RuNO}\}^{7}$ character. On the other hand, UV-vis spectroscopy does not support that conclusion. Over a long series of studies, 
we have established that the Soret maxima of a series of TpXPC complexes with varying para substituents X provides a simple probe of the question of corrole noninnocence. If the Soret maximum redshifts in response to increasingly electron-donating character of $X$, the corrole is noninnocent, with porphyrin $\mathrm{a}_{2 \mathrm{u}}$-type radical character. ${ }^{19}, 40,41,42,43,44,45,46$ On the other hand, if the Soret maximum is essentially invariant with respect to $X$, the corrole is innocent. ${ }^{24,47,18,48,49}$ Applying this criterion to the UV-vis spectra of $\mathrm{Ru}[\mathrm{T} p \mathrm{XPC}](\mathrm{NO})$ (Figure 5, Table 3), we may conclude that the Ru complexes are likely to be innocent, i.e., true $\{\mathrm{RuNO}\}^{6}$ species with corrole $^{3-}$ ligands.

Table 3. Spectroscopic and electrochemical properties: Soret $\lambda_{\max }(\mathrm{nm}), E_{1 / 2}$ values (V), and IR $v_{\text {RuNO }}\left(\mathrm{cm}^{-1}\right)$.

\begin{tabular}{|c|c|c|c|c|c|c|}
\hline Complex & $\lambda_{\max }$ & $E_{1 / 20 \times 2}$ & $E_{1 / 20 \times 1}$ & $E_{1 / 2 \mathrm{red}}$ & $\Delta E$ & V RuNO \\
\hline $\mathrm{Ru}\left[\mathrm{T} p \mathrm{CF}_{3} \mathrm{PC}\right](\mathrm{NO})$ & 404 & 1.05 & 0.73 & -0.64 & 1.37 & 1740 \\
\hline $\mathrm{Ru}(\mathrm{TPC})(\mathrm{NO})$ & 404 & 0.98 & 0.64 & -0.73 & 1.37 & 1733 \\
\hline $\mathrm{Ru}\left[\mathrm{T} p \mathrm{CH}_{3} \mathrm{PC}\right](\mathrm{NO})$ & 404 & 0.95 & 0.63 & -0.74 & 1.37 & 1730 \\
\hline $\mathrm{Ru}\left[\mathrm{T} p \mathrm{OCH}_{3} \mathrm{PC}\right](\mathrm{NO})$ & 404 & 0.82 & 0.61 & -0.73 & 1.34 & 1727 \\
\hline $\mathrm{Ru}\left[\mathrm{T} p \mathrm{CF}_{3} \mathrm{PC}\right](\mathrm{N})$ & 417 & 1.37 & 0.98 & -1.16 & 2.14 & 1061 \\
\hline $\mathrm{Ru}[\mathrm{TPC}](\mathrm{N})$ & 418 & 1.33 & 0.88 & -1.32 & 2.20 & 1061 \\
\hline $\mathrm{Ru}\left[\mathrm{T} p \mathrm{CH}_{3} \mathrm{PC}\right](\mathrm{N})$ & 418 & 1.31 & 0.84 & -1.30 & 2.14 & 1061 \\
\hline $\mathrm{Ru}\left[\mathrm{T} p \mathrm{OCH}_{3} \mathrm{PC}\right](\mathrm{N})$ & 419 & 1.20 & 0.79 & -1.35 & 2.14 & 1061 \\
\hline $\mathrm{Os}\left[\mathrm{T} p \mathrm{CF}_{3} \mathrm{PC}\right](\mathrm{N})$ & 441 & 1.45 & 1.02 & -1.19 & 2.21 & - \\
\hline Os[TPC](N) & 442 & 1.32 & 0.91 & -1.28 & 2.19 & - \\
\hline $\mathrm{Os}\left[\mathrm{T} p \mathrm{CH}_{3} \mathrm{PC}\right](\mathrm{N})$ & 443 & 1.28 & 0.87 & -1.33 & 2.20 & - \\
\hline $\mathrm{Os}\left[\mathrm{T} p \mathrm{OCH}_{3} \mathrm{PC}\right](\mathrm{N})$ & 445 & 1.18 & 0.83 & -1.32 & 2.15 & - \\
\hline
\end{tabular}

DFT (B3LYP/STO-TZ2P) calculations also provide strong support for an innocent formulation of RuNO corroles. Thus, B3LYP/STO-TZ2P calculations failed to yield a brokensymmetry solution for Ru[TPC](NO), as they do for Fe[TPC](NO). Both DFT calculations and high-quality X-ray structures also indicate skeletal bond distance alternations of $\sim 0.02 \AA$ within the bipyrrole part of FeNO corrole structures, consistent with removal of an electron from the 
porphyrin $\mathrm{a}_{2 \mathrm{u}}$-like HOMO of the corrole macrocycle. As shown in Figure 6, the optimized structure of $\mathrm{Ru}[\mathrm{TPC}](\mathrm{NO})$ does not exhibit such a distance alternation. The X-ray structure of $\mathrm{Fe}[\mathrm{TPFPC}](\mathrm{NO})$ also evinces no indication of such an alternation. The conclusion that FeNO and RuNO corroles conform to different electronic descriptions, i.e., $\{\mathrm{FeNO}\}^{7}$-corrole $^{\cdot 2-}$ vs. $\left\{\mathrm{RuNO}^{6}{ }^{6}\right.$-corrole $^{3-}$, while interesting, should not be viewed as particularly surprising, given the increased stability of higher oxidation states for $4 \mathrm{~d}$ relative to $3 \mathrm{~d}$ transition metals.

The redox potentials of RuNO corroles are consistent with above electronic-structural picture. Thus, as corrole ${ }^{3-}$ derivatives, RuNO corroles are some $200 \mathrm{mV}$ easier to oxidize than analogous FeNO corroles, which are corrole ${ }^{2-}$. Thus, the $E_{1 / 20 x}$ for $\mathrm{Ru}[\mathrm{TPC}](\mathrm{NO})$ is $0.64 \mathrm{~V}$, while that of $\mathrm{Fe}[\mathrm{TPC}](\mathrm{NO})$ is $0.86 \mathrm{~V}$. A similar argument also accounts for the fact that the reduction potentials of RuNO corroles are some $400 \mathrm{mV}$ more negative (i.e., more difficult to reduce) than those of FeNO corroles. Thus, the $E_{1 / 2 \text { red }}$ for $\mathrm{Ru}[\mathrm{TPC}](\mathrm{NO})$ is $-0.73 \mathrm{~V}$, while that of $\mathrm{Fe}[\mathrm{TPC}](\mathrm{NO})$ is $-0.33 \mathrm{~V}$. The electrochemical HOMO-LUMO gaps are thus marginally higher for RuNO corroles than those of FeNO corroles. DFT (B3LYP/STO-TZ2P/COSMO) spin density plots further indicate that the cationic and anionic states of $\mathrm{Ru}[\mathrm{TPC}](\mathrm{NO})$ are best viewed as $\left\{\mathrm{RuNO}^{6}{ }^{-}\right.$-corrole $^{\cdot 2-}$ and $\{\mathrm{RuNO}\}^{7}$-corrole $^{3-}$, respectively.

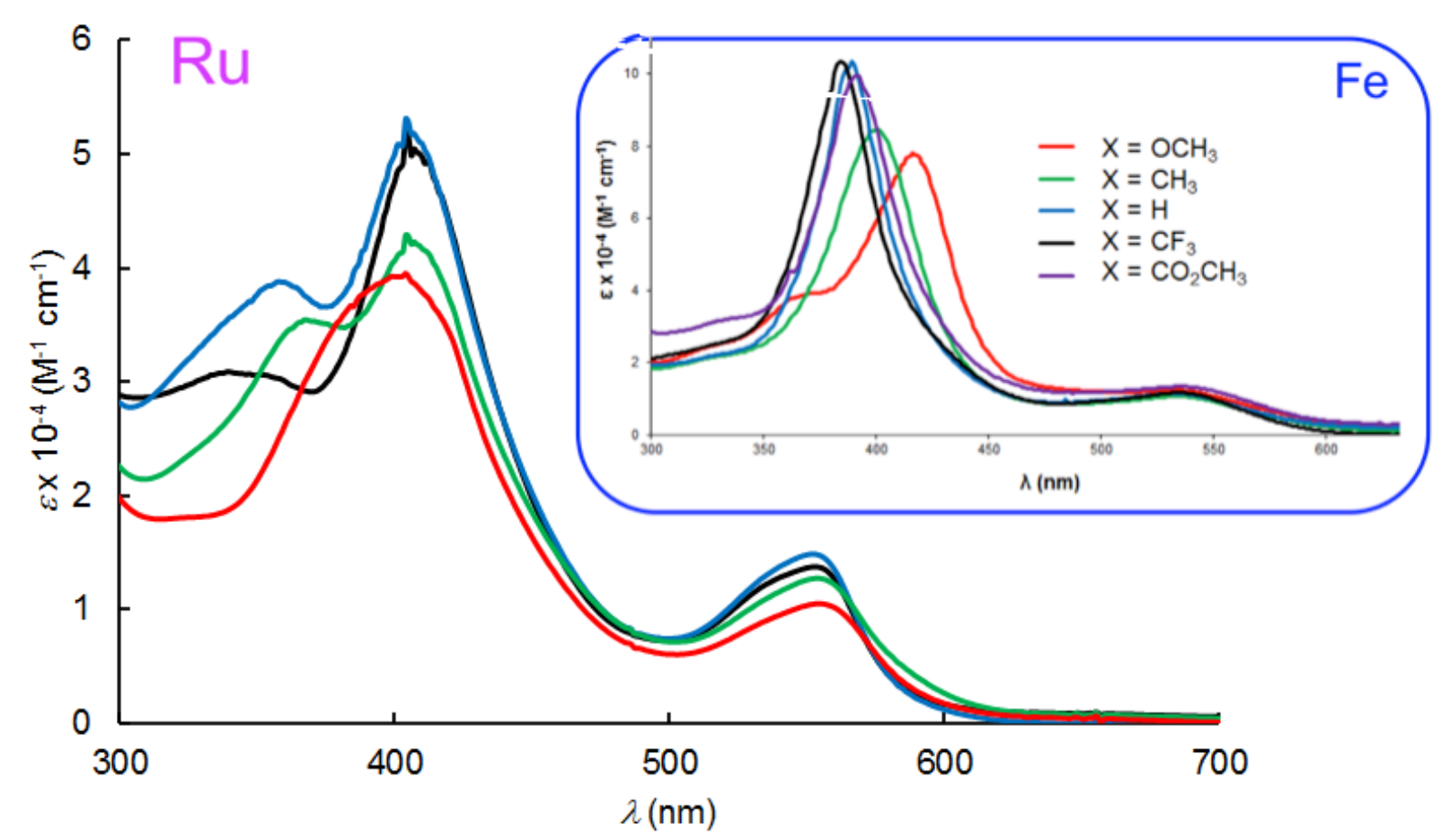

Figure 5. Comparison of the UV-vis spectra of Ru[TpXPC](NO) and Fe[TpXPC](NO) (inset) in dichloromethane. 


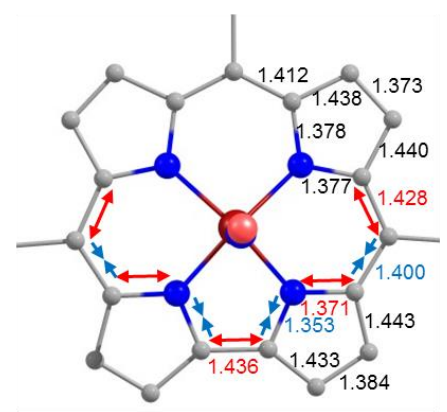

$\mathrm{Fe}[\mathrm{TPC}](\mathrm{NO})$ B3LYP/TZ2P

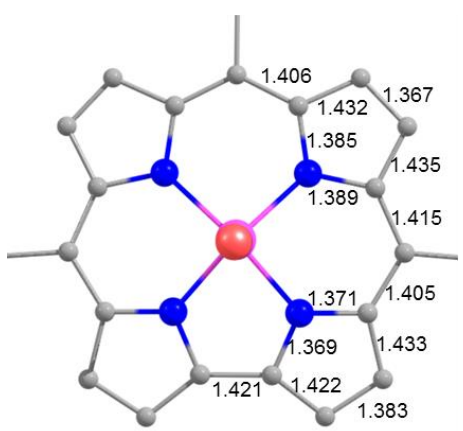

$\mathrm{Ru}[\mathrm{TPC}](\mathrm{NO})$ B3LYP/TZ2P

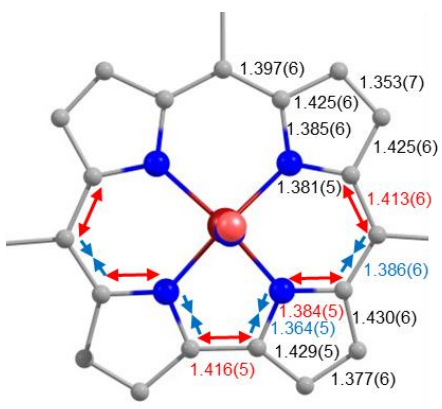

$\mathrm{Fe}[\mathrm{TPFPC}](\mathrm{NO})$ AGULAP

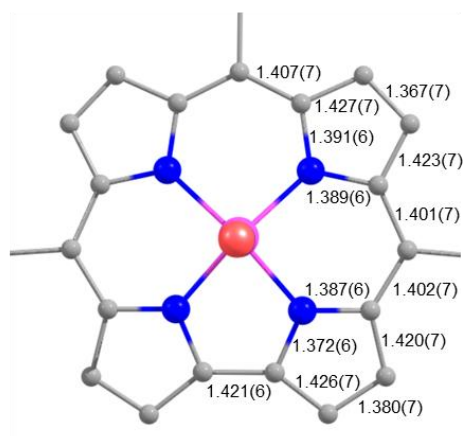

$\mathrm{Ru}[\mathrm{TPFPC}](\mathrm{NO})$ HUQJEI

Figure 6. Highlights of DFT and crystallographic bond distances $(\AA)$ for selected FeNO and RuNO corroles.

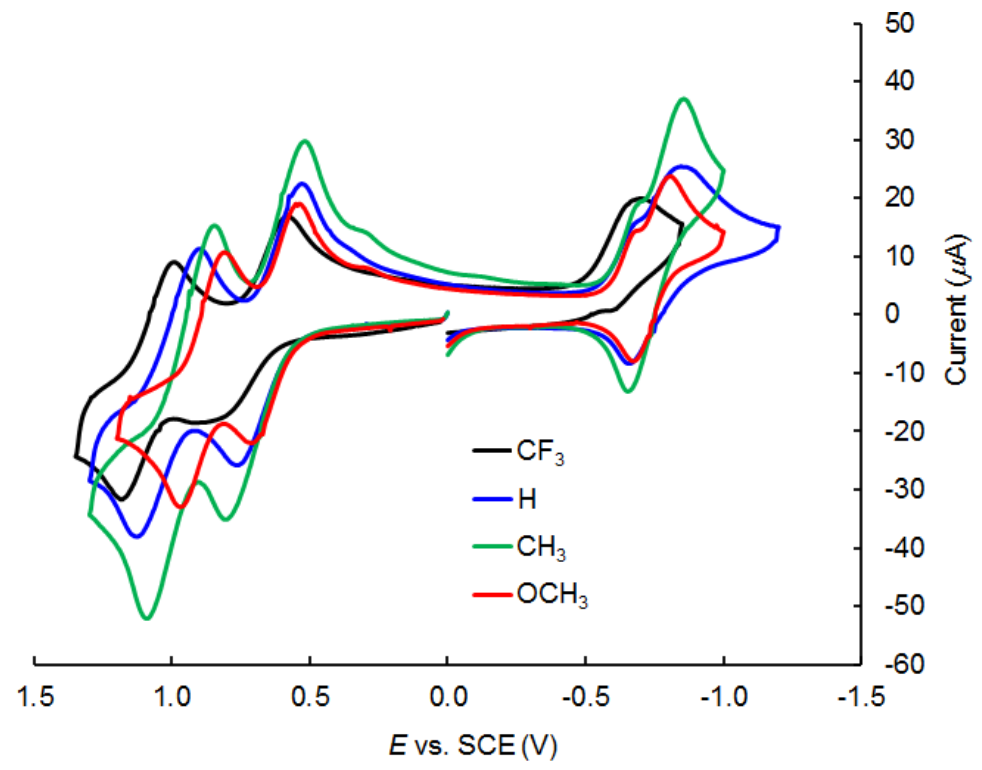

Figure 7. Comparative cyclic voltammograms (V vs. SCE, $\mathrm{CH}_{2} \mathrm{Cl}_{2}, 100 \mathrm{mV} / \mathrm{s}$ ) for $\mathrm{Ru}[\mathrm{T} p \mathrm{XPC}](\mathrm{NO})$. 

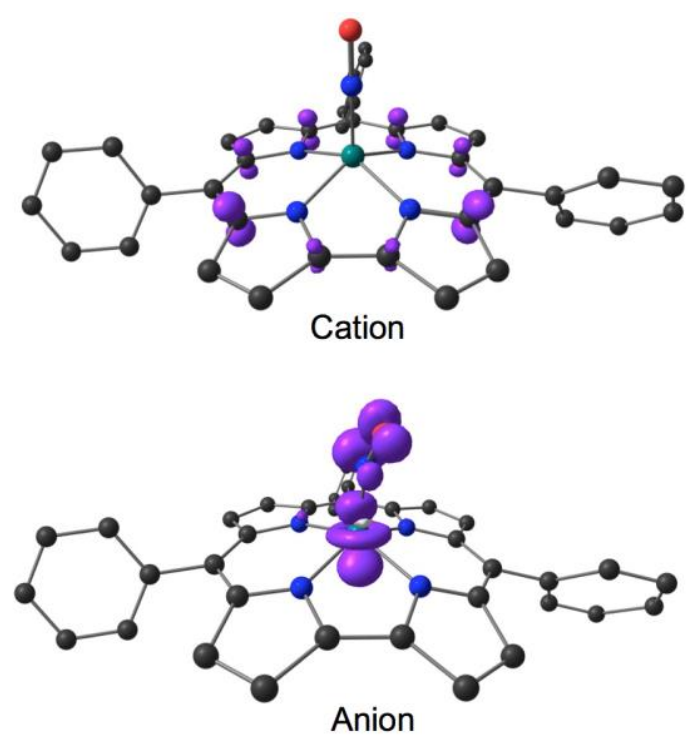

Figure 8. Spin density profiles of the cationic and anionic states of $\mathrm{Ru}[\mathrm{TPC}](\mathrm{NO})$.

(d) Electronic-structural aspects of $\mathrm{Ru}^{\mathrm{VI}} \mathrm{N}$ corroles. The $\mathrm{Ru}{ }^{\mathrm{VI}} \mathrm{N}$ triarylcorroles synthesized exhibit relatively high oxidation potentials of 0.8 to $1.0 \mathrm{~V}$ and low reduction potentials of -1.33 to $-1.19 \mathrm{~V}$, which translate to electrochemical HOMO-LUMO gaps of about $2.2 \mathrm{~V}$, essentially identical to those observed for $\mathrm{Os}^{\mathrm{VI}} \mathrm{N}$ corroles. These redox potentials are indicative of ligand $\pi$-system-based processes, suggesting an innocent corrole macrocycle. The intense and exceptionally sharp Soret bands of the compounds also strongly suggest an innocent corrole ligand (Figure 9). A fascinating point here is that the Soret maxima of the $\mathrm{Ru}^{\mathrm{VI}} \mathrm{N}$ complexes are blue-shifted by some $25 \mathrm{~nm}$ relative to those of the analogous $\mathrm{Os}^{\mathrm{VI}} \mathrm{N}$ complexes (Figure 9). ${ }^{24}$ A similar spectral shift was also recently noted for the Soret maxima of $\mathrm{Tc}^{\mathrm{V}} \mathrm{O}^{48} \mathrm{Vs}$. $\mathrm{Re}^{\mathrm{V}} \mathrm{O}^{49}$ corroles; a careful TDDFT analysis indicated that the redshifted Soret maxima of ReO corroles could be ascribed to relativistic effects. Detailed studies of relativistic effects are scarce for metalloporphyrin-type complexes so an analogous TDDFT (B3LYP-D3/COSMO) study was also undertaken to gain insight into the spectral shift between $\mathrm{Ru}^{\mathrm{VI}} \mathrm{N}$ and $\mathrm{Os}^{\mathrm{VI}} \mathrm{N}$ corroles (Figure 10). The calculations showed that the $\mathrm{Os}^{\mathrm{VI}} \mathrm{N}$ case corresponds to the classic Gouterman fourorbital scenario, with essentially no contribution from the relativistically destabilized Os(5d) orbitals to the four frontier MOs. In the $\mathrm{Ru}^{\mathrm{VI}} \mathrm{N}$ case, on the other hand, antibonding interactions with the $\mathrm{Ru}\left(4 \mathrm{~d}_{\mathrm{xz}, \mathrm{yz}}\right)$ orbitals results in higher-energy Gouterman LUMOs, leading to a blueshifted Soret band. 
(a)

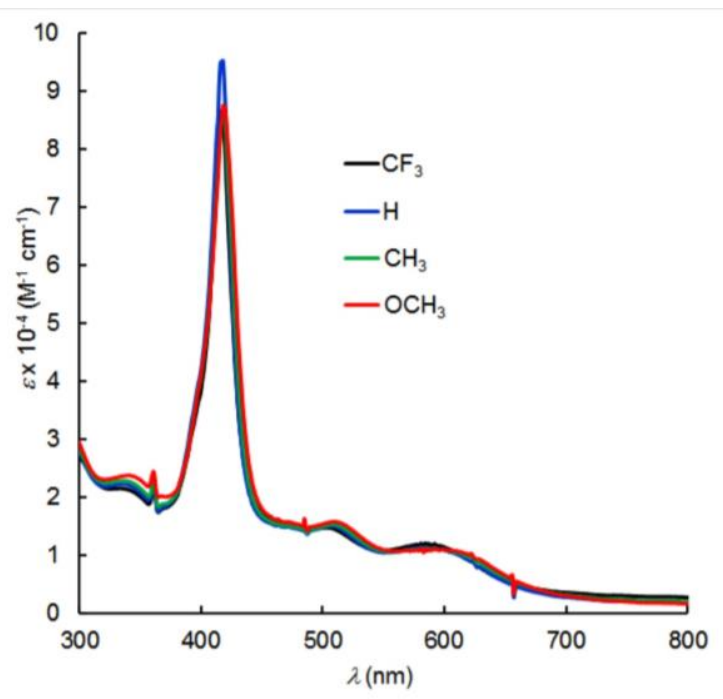

(b)

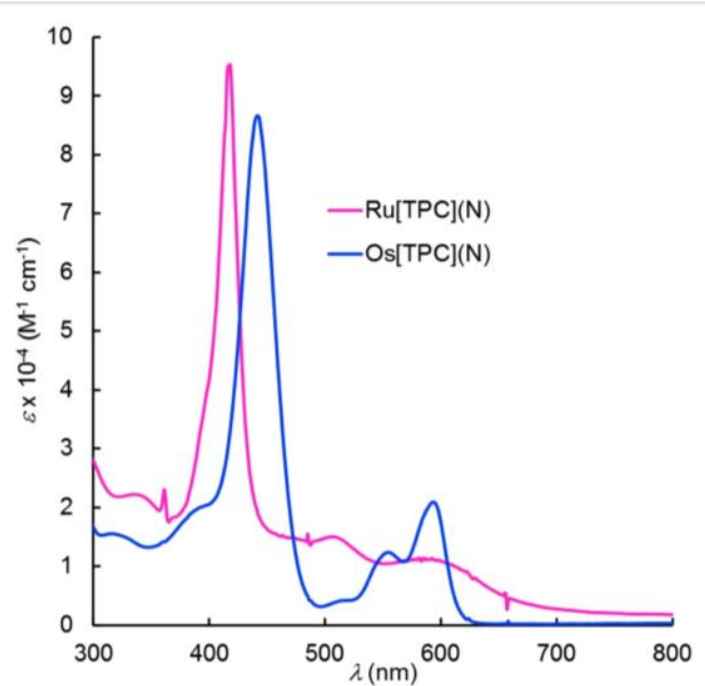

Figure 9. Electronic absorption spectra in dichloromethane for (a) $\mathrm{Ru}[\mathrm{T} p \mathrm{XPC}](\mathrm{N})$ and (b) $\mathrm{M}[\mathrm{TPC}](\mathrm{N})(\mathrm{M}=\mathrm{Ru}, \mathrm{Os})$. 

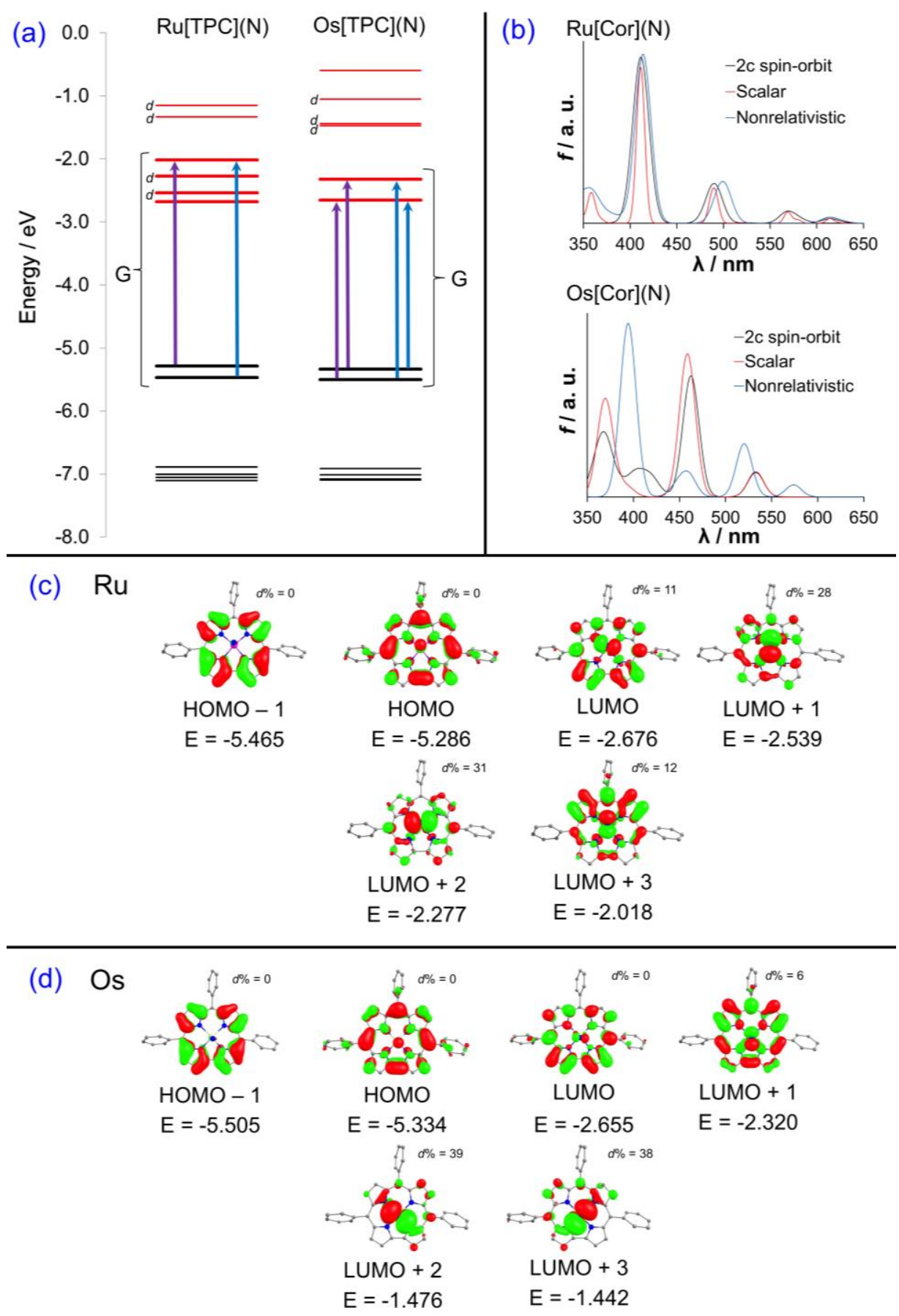

Figure 10. Selected DFT and TDDFT results on $\mathrm{M}[\mathrm{TPC}](\mathrm{N})(\mathrm{M}=\mathrm{Ru}$, Os). (a) Main contributions to the two Soret transitions of the two complexes; the label $d$ indicates MOs with $>25 \%$ metal d character; the energy range marked $\mathrm{G}$ is that spanned by the Goutermann-type frontier MOs. (b) Nonrelativistic, scalar relativistic, and spin-orbit TDDFT simulations of the electronic absorption spectra $\mathrm{M}[\mathrm{Cor}](\mathrm{N})$, where Cor = unsubstituted corrole. (c) Selected frontier MOs of Ru[TPC](N). (d) Selected frontier MOs of Os[TPC](N). 
Conclusion. The interaction of free-base corroles, $\left[\mathrm{Ru}(\mathrm{COD}) \mathrm{Cl}_{2}\right]_{2}$, and nitrite in refluxing 2-methoxyethanol has been shown to provide reliable access to two new families of $\mathrm{Ru}$ triarylcorroles, $\mathrm{Ru}[\mathrm{T} p \mathrm{XPC}](\mathrm{NO})$ and $\mathrm{Ru}^{\mathrm{VI}}[\mathrm{T} p \mathrm{XPC}](\mathrm{N})$. Both are thought to arise via the stepwise deoxygenation of nitrite, with the RuNO complexes forming in a matter of seconds and the $\mathrm{Ru}^{\mathrm{VI}} \mathrm{N}$ over several hours. The new complexes have shed light on periodic trends and relativistic effects for Group 8 metallocorroles. Thus, whereas FeNO corroles are thought of as noninnocent, i.e., $\{\mathrm{FeNO}\}^{7}$-corrole $^{\cdot 2-}$, RuNO corroles appear to conform to an innocent electronic-structural description, $\{\mathrm{RuNO}\}^{6}$-corrole $^{3-}$. We have also uncovered a remarkable spectral shift between the Soret maxima of $\mathrm{Ru}^{\mathrm{VI}} \mathrm{N}$ and $\mathrm{Os}^{\mathrm{VI}} \mathrm{N}$ corroles, with the latter redshifted by some $25 \mathrm{~nm}$. A careful TDDFT analysis has established that this shift may be largely ascribed to relativistic effects on the $\mathrm{Os}(5 \mathrm{~d})$ orbitals. The new Ru corroles reported herein are potential harbingers of new catalysts for organic transformations (such as aziridination and cyclopropanations) and of new anticancer and antimicrobial agents. These applications are currently under active investigation in our laboratory and will be reported in due course.

\section{Experimental section}

(a) Materials. Anhydrous 2-methoxyethanol (99.8\%), dichloro(1,5cyclooctadiene)ruthenium(II) polymer (95\%), diiodo( $p$-cymene)ruthenium(II) dimer, trimethylamine (99\%), sodium azide (99.5\%), and activated neutral alumina (Brockmann I) were purchased from Sigma-Aldrich and used as received. Silica gel 60 (0.04-0.063 mm particle size, 230-400 mesh, Merck) was employed for flash chromatography. Silica gel 60 preparative thin-layer chromatographic plates $(20 \mathrm{~cm}$ x $20 \mathrm{~cm}, 0.5 \mathrm{~mm}$ thick, Merck) were used for final purification of all complexes.

(b) Instrumental methods. UV-visible spectra were recorded on an HP 8453 spectrophotometer. ${ }^{1} \mathrm{H}$ NMR spectra $\left(253 \mathrm{~K}, \mathrm{CD}_{2} \mathrm{Cl}_{2}\right)$ were recorded on a $400 \mathrm{MHz}$ Bruker Avance III HD spectrometer equipped with a $5 \mathrm{~mm} \mathrm{BB} / 1 \mathrm{H}$ SmartProbe and referenced to residual $\mathrm{CH}_{2} \mathrm{Cl}_{2}$ at $5.31 \mathrm{ppm}$. High-resolution electrospray-ionization (HR-ESI) mass spectra were recorded from methanolic solution on an LTQ Orbitrap XL spectrometer. IR spectra were acquired as an average of 32 scans with a $1 \mathrm{~cm}^{-1}$ resolution on a Varian 7000e FT-IR spectrometer. Cyclic voltammetry measurements were carried out at $298 \mathrm{~K}$ with an EG\&G Model 263A potentiostat having a three electrode system: a glassy carbon working electrode, a 
platinum wire counterelectrode, and a saturated calomel reference electrode (SCE). Anhydrous $\mathrm{CH}_{2} \mathrm{Cl}_{2}$ (Aldrich) was used as solvent and tetra(n-butyl)ammonium perchlorate, recrystallized twice from absolute ethanol and dried in a desiccator for at least 2 weeks, was used as the supporting electrolyte. The reference electrode was separated from the bulk solution by a frittedglass bridge filled with the solvent/supporting electrolyte mixture. The electrolyte solution was purged with argon for at least 2 min and all measurements were carried out under an argon blanket. All potentials were referenced to the SCE. Elemental analyses were obtained from Atlantic Microlab Inc., USA.

\section{General Procedure for the synthesis of $\mathbf{R u}[\mathbf{T} p X P C](N O)$. A solution of $\mathrm{H}_{3}[\mathrm{~T} p \mathrm{XPC}]$}

$(0.136 \mathrm{mmol})$ in 2-methoxyethanol $(10 \mathrm{~mL})$ was brought to reflux under argon. To the hot solution was added trimethylamine $(50 \mu \mathrm{L})$, followed by $\left[\left\{\mathrm{Ru}(\operatorname{cod}) \mathrm{Cl}_{2}\right\}_{\mathrm{x}}\right](115 \mathrm{mg}, 0.41 \mathrm{mmol}$ $\mathrm{Ru}$ ). Within about $30 \mathrm{~s}$ of the addition of the $\left[\left\{\mathrm{Ru}(\operatorname{cod}) \mathrm{Cl}_{2}\right\}_{\mathrm{x}}\right]$ (during which the solution started to turn from green to brownish) was injected $0.5 \mathrm{~mL}$ of a saturated aqueous solution of sodium nitrite. Seconds later, the solution turned deep red and heating was discontinued. The solution, while stirring, was cooled to room temperature and evaporated to dryness. The resulting residue was dissolved in a minimum amount of dichloromethane and chromatographed on a neutral alumina column with 3:1 hexane/dichloromethane as eluent. Dimeric Ru corroles eluted first and upon their complete removal (as monitored by UV-vis spectroscopy) the eluent was changed to pure dichloromethane, which resulted in the elution of $\mathrm{Ru}[\mathrm{T} p \mathrm{XPC}](\mathrm{NO})$ as wine-red solutions. Two of Ru-corrole dimers and all four RuNO corroles were fully characterized.

$\left\{\mathbf{R u}\left[\mathbf{T p} \mathbf{C F} \mathbf{F}_{3} \mathbf{P C}\right]\right\}_{2}$. Yield $17.25 \mathrm{mg}(15.3 \%)$. UV-vis $\left(\mathrm{CH}_{2} \mathrm{Cl}_{2}\right): \lambda_{\max }(\mathrm{nm}),\left[\varepsilon \times 10^{-4}\left(\mathrm{M}^{-}\right.\right.$ $\left.{ }^{1} \mathrm{~cm}^{-1}\right)$ ]: 328 (8.83), 397 (7.82), 541(1.88). ${ }^{1} \mathrm{H}$ NMR (400 MHz, $\left.-20^{\circ} \mathrm{C}\right): \delta 9.10\left(\mathrm{~d}, 2 \mathrm{H},{ }^{3} J_{\mathrm{HH}}=\right.$ $8.0 \mathrm{~Hz}, 10-o 1-\mathrm{Ph}) ; 8.99\left(\mathrm{~d}, 4 \mathrm{H},{ }^{3} J_{\mathrm{HH}}=8.0 \mathrm{~Hz}, 5,15-o 1-\mathrm{Ph}\right) ; 8.83\left(\mathrm{~d}, 4 \mathrm{H},{ }^{3} J_{\mathrm{HH}}=3.5 \mathrm{~Hz}, \beta-\mathrm{H}\right)$; $8.66\left(\mathrm{~d}, 4 \mathrm{H},{ }^{3} J_{\mathrm{HH}}=4.2 \mathrm{~Hz}, \beta-\mathrm{H}\right) ; 8.35(\mathrm{bs}, 8 \mathrm{H}, \beta-\mathrm{H}) ; 8.15$ (overlapping doublets, $6 \mathrm{H},{ }^{3} J_{\mathrm{HH}}=9.5$ $\mathrm{Hz}, 10-m 1-\mathrm{Ph} \& 5,15-m 1-\mathrm{Ph}) ; 7.86\left(\mathrm{~d}, 4 \mathrm{H},{ }^{3} J_{\mathrm{HH}}=8.0 \mathrm{~Hz}, 5,15-o 2-\mathrm{Ph}\right) ; 7.80\left(\mathrm{~d}, 2 \mathrm{H},{ }^{3} J_{\mathrm{HH}}=8.5\right.$ $\mathrm{Hz}, 10-o 2-\mathrm{Ph}) ; 7.53\left(\mathrm{~d}, 4 \mathrm{H},{ }^{3} J_{\mathrm{HH}}=8.0 \mathrm{~Hz}, 5,15-m 2-\mathrm{Ph}\right) ; 7.37$ (d, 2H, $\left.{ }^{3} J_{\mathrm{HH}}=7.7 \mathrm{~Hz}, 10-o 2-\mathrm{Ph}\right)$. Elemental analysis: Found C 57.69, H 2.62, N 6.32; calcd C 57.98, H 2.43, N 6.76. MS (ESI): $\mathrm{M}^{+}=1658.11$ (expt), 1658.12 (calcd for $\mathrm{C}_{80} \mathrm{H}_{40} \mathrm{~F}_{18} \mathrm{~N}_{8} \mathrm{Ru}_{2}$ )

$\{\mathbf{R u}[\mathbf{T P C}]\}_{2}$. Yield $14.96 \mathrm{mg}(17.6 \%)$. UV-vis $\left(\mathrm{CH}_{2} \mathrm{Cl}_{2}\right): \lambda_{\max }(\mathrm{nm}),\left[\varepsilon \times 10^{-4}\left(\mathrm{M}^{-1} \mathrm{~cm}^{-1}\right)\right]$ : 328 (9.06), 397 (7.74), 539 (1.99). ${ }^{1} \mathrm{H}$ NMR (400 MHz, $-20^{\circ} \mathrm{C}$ ): $\delta 9.05$ (d, 4H, ${ }^{3} J_{\mathrm{HH}}=7.2 \mathrm{~Hz}$, $5,15-o 1-\mathrm{Ph}) ; 8.93\left(\mathrm{~d}, 2 \mathrm{H},{ }^{3} \mathrm{~J}_{\mathrm{HH}}=8.2 \mathrm{~Hz}, 10-o 1-\mathrm{Ph}\right) ; 8.77$ (bs, 4H, $\left.\beta-\mathrm{H}\right) ; 8.60(\mathrm{bs}, 4 \mathrm{H}, \beta-\mathrm{H}) ; 8.29$ (bs, $8 \mathrm{H}, \beta-\mathrm{H}) ; 7.99$ (t, $\left.4 \mathrm{H},{ }^{3} J_{\mathrm{HH}}=7.2 \mathrm{~Hz}, 5,15-m 1-\mathrm{Ph}\right) ; 7.82$ (t, $2 \mathrm{H},{ }^{3} J_{\mathrm{HH}}=7.2 \mathrm{~Hz}, 10-m 1-\mathrm{Ph}$ ); 
$7.75\left(\mathrm{t}, 4 \mathrm{H},{ }^{3} J_{\mathrm{HH}}=7.2 \mathrm{~Hz}, 5,15-p-\mathrm{Ph}\right) ; 7.69\left(\mathrm{t}, 2 \mathrm{H},{ }^{3} J_{\mathrm{HH}}=7.2 \mathrm{~Hz}, 10-p-\mathrm{Ph}\right) ; 7.55\left(\mathrm{t}, 4 \mathrm{H},{ }^{3} J_{\mathrm{HH}}=\right.$ $7.2 \mathrm{~Hz}, 5,15-m 2-\mathrm{Ph}) ; 7.45\left(\mathrm{t}, 2 \mathrm{H},{ }^{3} J_{\mathrm{HH}}=7.2 \mathrm{~Hz}, 10-m 2-\mathrm{Ph}\right) ; 7.33\left(\mathrm{~d}, 4 \mathrm{H},{ }^{3} J_{\mathrm{HH}}=8.2 \mathrm{~Hz}, 5,15-o 2-\right.$ $\mathrm{Ph}) ; 7.13\left(\mathrm{~d}, 2 \mathrm{H},{ }^{3} \mathrm{~J}_{\mathrm{HH}}=7.2 \mathrm{~Hz}, 10-m 2-\mathrm{Ph}\right)$. Elemental analysis: Found: C 70.85, H 3.49, N 8.62; calcd: C 71.14, H 3.71, N 8.97. MS (ESI): $\mathrm{M}^{+}=1250.20$ (expt), 1250.19 (calcd for $\mathrm{C}_{74} \mathrm{H}_{46} \mathrm{~N}_{8} \mathrm{Ru}_{2}$ ).

Ru[TpCF 3 PC](NO). Yield $51 \mathrm{mg}(43.67 \%)$. UV-vis $\left(\mathrm{CH}_{2} \mathrm{Cl}_{2}\right): \lambda_{\max }(\mathrm{nm}),\left[\varepsilon \times 10^{-4}\left(\mathrm{M}^{-}\right.\right.$ $\left.{ }^{1} \mathrm{~cm}^{-1}\right)$ ]: 339 (3.09), 404 (5.18), 553 (1.38). $\left.{ }^{1} \mathrm{H} \mathrm{NMR} \mathrm{(400} \mathrm{MHz,}-20^{\circ} \mathrm{C}\right): \delta 9.21\left(\mathrm{~d}, 2 \mathrm{H},{ }^{3} J_{\mathrm{HH}}=\right.$ $4.5 \mathrm{~Hz}, \beta-\mathrm{H}) ; 8.80\left(\mathrm{~d}, 2 \mathrm{H},{ }^{3} \mathrm{~J}_{\mathrm{HH}}=4.8 \mathrm{~Hz}, \beta-\mathrm{H}\right) ; 8.75\left(\mathrm{~d}, 2 \mathrm{H},{ }^{3} J_{\mathrm{HH}}=4.5 \mathrm{~Hz}, \beta-\mathrm{H}\right) ; 8.58(\mathrm{~d}, 2 \mathrm{H}$, $\left.{ }^{3} J_{\mathrm{HH}}=4.8 \mathrm{~Hz}, \beta-\mathrm{H}\right) ; 8.55\left(\mathrm{~d}, 2 \mathrm{H},{ }^{3} J_{\mathrm{HH}}=8.1 \mathrm{~Hz}, 5,15-o 1-\mathrm{Ph}\right) ; 8.44\left(\mathrm{~d}, 1 \mathrm{H},{ }^{3} J_{\mathrm{HH}}=7.9 \mathrm{~Hz}, 10-o 1-\right.$ $\mathrm{Ph}) ; 8.15\left(\mathrm{~d}, 2 \mathrm{H},{ }^{3} J_{\mathrm{HH}}=8.2 \mathrm{~Hz}, 5,15-m 1-\mathrm{Ph}\right) ; 8.12\left(\mathrm{~d}, 2 \mathrm{H},{ }^{3} J_{\mathrm{HH}}=8.4 \mathrm{~Hz}, 5,15-o 2-\mathrm{Ph}\right) ; 8.09(\mathrm{~d}$, $\left.1 \mathrm{H},{ }^{3} J_{\mathrm{HH}}=8.1 \mathrm{~Hz}, 10-m 1-\mathrm{Ph}\right) ; 8.06\left(\mathrm{~d}, 1 \mathrm{H},{ }^{3} J_{\mathrm{HH}}=7.9 \mathrm{~Hz}, 10-o 2-\mathrm{Ph}\right) ; 8.02\left(\mathrm{~d}, 2 \mathrm{H},{ }^{3} J_{\mathrm{HH}}=8.1 \mathrm{~Hz}\right.$, 5,15-m2-Ph); 7.98 (d, 2H, $\left.{ }^{3} J_{\mathrm{HH}}=8.2 \mathrm{~Hz}, 10-m 2-\mathrm{Ph}\right)$. Elemental analysis: Found: C 56.39, H 2.51, N 7.87; calcd: C 55.95, H 2.35, N 8.16. MS (ESI): $\mathrm{M}^{+}=859.05$ (expt), 858.68 (calcd for $\left.\mathrm{C}_{40} \mathrm{H}_{20} \mathrm{OF}_{9} \mathrm{~N}_{5} \mathrm{Ru}\right)$. IR $v_{\mathrm{RuNO}}: 1740 \mathrm{~cm}^{-1}$.

Ru(TPC)(NO). Yield $38.49 \mathrm{mg}(43.24 \%)$. UV-vis $\left(\mathrm{CH}_{2} \mathrm{Cl}_{2}\right): \lambda_{\max }(\mathrm{nm}),\left[\varepsilon \times 10^{-4}\left(\mathrm{M}^{-}\right.\right.$ $\left.{ }^{1} \mathrm{~cm}^{-1}\right)$ ]: 360 (3.87), 404 (5.31), 552 (1.49). ${ }^{1} \mathrm{H}$ NMR (400 MHz, $\left.-20^{\circ} \mathrm{C}\right): \delta 9.14\left(\mathrm{~d}, 2 \mathrm{H},{ }^{3} J_{\mathrm{HH}}=\right.$ $4.5 \mathrm{~Hz}, \beta-\mathrm{H}) ; 8.80\left(\mathrm{~d}, 2 \mathrm{H},{ }^{3} J_{\mathrm{HH}}=4.8 \mathrm{~Hz}, \beta-\mathrm{H}\right) ; 8.75\left(\mathrm{~d}, 2 \mathrm{H},{ }^{3} J_{\mathrm{HH}}=4.5 \mathrm{~Hz}, \beta-\mathrm{H}\right) ; 8.58(\mathrm{~d}, 2 \mathrm{H}$, $\left.{ }^{3} J_{\mathrm{HH}}=4.8 \mathrm{~Hz}, \beta-\mathrm{H}\right) ; 8.41\left(\mathrm{~d}, 2 \mathrm{H},{ }^{3} J_{\mathrm{HH}}=7.5 \mathrm{~Hz}, 5,15-o 1-\mathrm{Ph}\right) ; 8.28\left(\mathrm{~d}, 1 \mathrm{H},{ }^{3} J_{\mathrm{HH}}=7.5 \mathrm{~Hz}, 10-o 1-\right.$ $\mathrm{Ph}) ; 8.04\left(\mathrm{~d}, 2 \mathrm{H},{ }^{3} J_{\mathrm{HH}}=7.8 \mathrm{~Hz}, 5,15-o 2-\mathrm{Ph}\right) ; 7.92\left(\mathrm{~d}, 1 \mathrm{H},{ }^{3} J_{\mathrm{HH}}=7.0 \mathrm{~Hz}, 10-o 2-\mathrm{Ph}\right) ; 7.88-7.65$ (m, 9H, Ph). Elemental analysis: Found: C 66.43, H 3.93, N 9.87; calcd: C 67.88, H 3.54, N 10.70. MS (ESI): $\mathrm{M}^{+}=655.09$ (expt), 654.68 (calcd for $\mathrm{C}_{37} \mathrm{H}_{23} \mathrm{~N}_{5} \mathrm{ORu}$ ). IR v RuNO: $1733 \mathrm{~cm}^{-1}$. $\mathbf{R u}\left[\mathbf{T p} \mathbf{C H} \mathrm{H}_{3} \mathbf{P C}\right](\mathbf{N O})$. Yield $46.87 \mathrm{mg}(49.47 \%)$. UV-vis $\left(\mathrm{CH}_{2} \mathrm{Cl}_{2}\right): \lambda_{\max }(\mathrm{nm}),\left[\varepsilon \times 10^{-4}\right.$ $\left(\mathrm{M}^{-1} \mathrm{~cm}^{-1}\right)$ ]: 368 (3.54), 404 (4.28), 554 (1.27). ${ }^{1} \mathrm{H}$ NMR (400 MHz, $\left.-20^{\circ} \mathrm{C}\right): \delta 9.12\left(\mathrm{~d}, 2 \mathrm{H},{ }^{3} J_{\mathrm{HH}}\right.$ $=4.4 \mathrm{~Hz}, \beta-\mathrm{H}) ; 8.80\left(\mathrm{~d}, 2 \mathrm{H},{ }^{3} J_{\mathrm{HH}}=4.8 \mathrm{~Hz}, \beta-\mathrm{H}\right) ; 8.73\left(\mathrm{~d}, 2 \mathrm{H},{ }^{3} J_{\mathrm{HH}}=4.5 \mathrm{~Hz}, \beta-\mathrm{H}\right) ; 8.57(\mathrm{~d}, 2 \mathrm{H}$, $\left.{ }^{3} J_{\mathrm{HH}}=4.9 \mathrm{~Hz}, \beta-\mathrm{H}\right) ; 8.28\left(\mathrm{~d}, 2 \mathrm{H},{ }^{3} J_{\mathrm{HH}}=7.6 \mathrm{~Hz}, 5,15-o 1-\mathrm{Ph}\right) ; 8.14\left(\mathrm{~d}, 1 \mathrm{H},{ }^{3} J_{\mathrm{HH}}=7.7 \mathrm{~Hz}, 10-o 1-\right.$ $\mathrm{Ph}) ; 7.91\left(\mathrm{~d}, 2 \mathrm{H},{ }^{3} J_{\mathrm{HH}}=7.7 \mathrm{~Hz}, 5,15-o 2-\mathrm{Ph}\right) ; 7.79\left(\mathrm{~d}, 1 \mathrm{H},{ }^{3} J_{\mathrm{HH}}=7.7 \mathrm{~Hz}, 10-o 2-\mathrm{Ph}\right) ; 7.65(\mathrm{~d}, 2 \mathrm{H}$, $\left.{ }^{3} J_{\mathrm{HH}}=7.9 \mathrm{~Hz}, 5,15-m 1-\mathrm{Ph}\right) ; 7.60\left(\mathrm{~d}, 1 \mathrm{H},{ }^{3} J_{\mathrm{HH}}=8.1 \mathrm{~Hz}, 10-m 1-\mathrm{Ph}\right) ; 7.55\left(\mathrm{~d}, 2 \mathrm{H},{ }^{3} J_{\mathrm{HH}}=7.8 \mathrm{~Hz}\right.$, 5,15-m2-Ph); $7.51\left(\mathrm{~d}, 1 \mathrm{H},{ }^{3} \mathrm{~J}=7.9 \mathrm{~Hz}, 10-m 2-\mathrm{Ph}\right) ; 2.64$ (s, 6H, 10-p- $\left.\mathrm{CH}_{3}\right) ; 2.62$ (s, 3H, 10-p$\mathrm{CH}_{3}$ ). Elemental analysis: Found: C 69.33, H 4.45, N 9.55; calcd: C 68.95, H 4.20, N 10.05. MS (ESI): $\mathrm{M}^{+}=697.14$ (expt), 696.76 (calcd for $\mathrm{C}_{40} \mathrm{H}_{29} \mathrm{~N}_{5} \mathrm{ORu}$ ). IR v $v_{\mathrm{RuNO}}: 1730 \mathrm{~cm}^{-1}$. 
Ru[TpOMePC](NO). Yield $40.77 \mathrm{mg}(40.26 \%)$. UV-vis $\left(\mathrm{CH}_{2} \mathrm{Cl}_{2}\right): \lambda_{\max }(\mathrm{nm}),\left[\varepsilon \times 10^{-4}\right.$ $\left.\left(\mathrm{M}^{-1} \mathrm{~cm}^{-1}\right)\right]: 404$ (3.95), 555 (1.05). ${ }^{1} \mathrm{H} \mathrm{NMR}\left(400 \mathrm{MHz},-20^{\circ} \mathrm{C}\right): \delta 9.12\left(\mathrm{~d}, 2 \mathrm{H},{ }^{3} J_{\mathrm{HH}}=4.5 \mathrm{~Hz}, \beta-\right.$ $\mathrm{H}) ; 8.81\left(\mathrm{~d}, 2 \mathrm{H},{ }^{3} J_{\mathrm{HH}}=4.8 \mathrm{~Hz}, \beta-\mathrm{H}\right) ; 8.74\left(\mathrm{~d}, 2 \mathrm{H},{ }^{3} J_{\mathrm{HH}}=4.5 \mathrm{~Hz}, \beta-\mathrm{H}\right) ; 8.59\left(\mathrm{~d}, 2 \mathrm{H},{ }^{3} J_{\mathrm{HH}}=4.8\right.$ $\mathrm{Hz}, \beta-\mathrm{H}) ; 8.32\left(\mathrm{~d}, 2 \mathrm{H},{ }^{3} J_{\mathrm{HH}}=8.5 \mathrm{~Hz}, 5,15-o 1-\mathrm{Ph}\right) ; 8.19\left(\mathrm{~d}, 1 \mathrm{H},{ }^{3} J_{\mathrm{HH}}=8.2 \mathrm{~Hz}, 10-o 1-\mathrm{Ph}\right) ; 7.96$ $\left(\mathrm{d}, 2 \mathrm{H},{ }^{3} \mathrm{~J}_{\mathrm{HH}}=8.5 \mathrm{~Hz}, 5,15-o 2-\mathrm{Ph}\right) ; 7.84\left(\mathrm{~d}, 1 \mathrm{H},{ }^{3} \mathrm{~J}_{\mathrm{HH}}=8.2 \mathrm{~Hz}, 10-o 2-\mathrm{Ph}\right) ; 7.37\left(\mathrm{~d}, 2 \mathrm{H},{ }^{3} J_{\mathrm{HH}}=\right.$ $8.5 \mathrm{~Hz}, 5,15-m 1-\mathrm{Ph}) ; 7.32\left(\mathrm{~d}, 1 \mathrm{H},{ }^{3} J_{\mathrm{HH}}=8.2 \mathrm{~Hz}, 10-m 1-\mathrm{Ph}\right) ; 7.27\left(\mathrm{~d}, 2 \mathrm{H},{ }^{3} J_{\mathrm{HH}}=8.5 \mathrm{~Hz}, 5,15-\right.$ $m 2-\mathrm{Ph}) ; 7.22\left(\mathrm{~d}, 1 \mathrm{H},{ }^{3} \mathrm{~J}_{\mathrm{HH}}=8.2 \mathrm{~Hz}, 10-m 2-\mathrm{Ph}\right) ; 4.03$ (s, 6H, 5, 15- $\left.p-\mathrm{OCH}_{3}\right) ; 4.01$ (s, 3H, 10-p$\mathrm{OCH}_{3}$ ). Elemental analysis: Found C 63.04, H 4.50, N 8.79; calcd C 64.51, H 3.92, N 9.40. MS (ESI): $\mathrm{M}^{+}=745.12$ (expt), 744.76 (calcd for $\mathrm{C}_{40} \mathrm{H}_{29} \mathrm{O}_{4} \mathrm{~N}_{5} \mathrm{Ru}$ ). IR v $v_{\mathrm{RuNO}}: 1727 \mathrm{~cm}^{-1}$.

General procedure for the synthesis of $\mathbf{R u}[\mathbf{T} p X P C](\mathbf{N})$. A solution of $\mathrm{H}_{3}[\mathrm{~T} p X P C]$ $(0.136 \mathrm{mmol})$ in 2-methoxyethanol $(10 \mathrm{~mL})$ was brought to reflux under argon. To the hot solution was added trimethylamine $(50 \mu \mathrm{L})$, followed by $\left[\left\{\mathrm{Ru}(\operatorname{cod}) \mathrm{Cl}_{2}\right\}_{\mathrm{x}}\right](115 \mathrm{mg}, 0.41 \mathrm{mmol}$ $\mathrm{Ru}$ ). Within about $30 \mathrm{~s}$ of the addition of the $\left[\left\{\mathrm{Ru}(\operatorname{cod}) \mathrm{Cl}_{2}\right\}_{\mathrm{x}}\right]$ (during which the solution started to turn from green to brownish) was injected $0.5 \mathrm{~mL}$ of a saturated aqueous solution of sodium nitrite, resulting in (as before) a deep red solution. Heating was continued for $\sim 16 \mathrm{~h}$ and the solution was then cooled to room temperature. Upon evaporation of the solvent, the crude material was chromatographed on a neutral alumina column using with pure dichloromethane as eluent, which yielded $\mathrm{Ru}[\mathrm{T} p \mathrm{XPC}](\mathrm{N})$ as the first fraction. The eluent was then changed to 95:5 dichloromethane/methanol to elute the remaining products sticking to the column. ESI-MS analysis of the second fraction suggested the presence of binuclear $\mu$-nitrido ruthenium corroles among other unidentified products. This fraction of unidentified products was evaporated to dryness and redissolved in 2-methoxyethanol and refluxed for $2 \mathrm{~h}$ in the presence of sodium azide $(0.45 \mathrm{mmol})$. Upon evaporation of the solvent, the residue was chromatographed on a neutral alumina column with dichloromethane as eluent, resulting in a new batch of $\mathrm{Ru}[\mathrm{T} p \mathrm{XPC}](\mathrm{N})$. The two batches of RuN corrole were combined, evaporated to dryness, and further purified by chromatography on a silica gel column with 3:1 hexane/dichloromethane as eluent. Final purification was then achieved with preparative thin-layer chromatography on silica gel plates with 3:2 hexane/dichloromethane, which resulted in overall 11-18\% yields of RuN corroles (relative to the free-base corroles used).

$\mathbf{R u}\left[\mathbf{T} p \mathbf{C F}_{3} \mathbf{P C}\right](\mathbf{N})$. Yield $15.08 \mathrm{mg}(13.16 \%)$. UV-vis $\left(\mathrm{CH}_{2} \mathrm{Cl}_{2}\right): \lambda_{\max }(\mathrm{nm}),\left[\varepsilon \times 10^{-4}\left(\mathrm{M}^{-}\right.\right.$ $\left.{ }^{1} \mathrm{~cm}^{-1}\right)$ ]: 417 (8.65), 505 (1.47), 592 (1.19). ${ }^{1} \mathrm{H}$ NMR $\left(400 \mathrm{MHz},-20^{\circ} \mathrm{C}\right): \delta 9.61\left(\mathrm{~d}, 2 \mathrm{H},{ }^{3} J_{\mathrm{HH}}=\right.$ $4.4 \mathrm{~Hz}, \beta-\mathrm{H}) ; 9.27\left(\mathrm{~d}, 2 \mathrm{H},{ }^{3} J_{\mathrm{HH}}=4.9 \mathrm{~Hz}, \beta-\mathrm{H}\right) ; 9.17\left(\mathrm{~d}, 2 \mathrm{H},{ }^{3} J_{\mathrm{HH}}=4.5 \mathrm{~Hz}, \beta-\mathrm{H}\right) ; 9.03(\mathrm{~d}, 2 \mathrm{H}$, 
$\left.{ }^{3} J_{\mathrm{HH}}=4.9 \mathrm{~Hz}, \beta-\mathrm{H}\right) ; 8.66\left(\mathrm{~d}, 2 \mathrm{H},{ }^{3} J_{\mathrm{HH}}=8.1 \mathrm{~Hz}, 5,15-o 1-\mathrm{Ph}\right) ; 8.59\left(\mathrm{~d}, 1 \mathrm{H},{ }^{3} J_{\mathrm{HH}}=8.1 \mathrm{~Hz}, 10-o 1-\right.$ $\mathrm{Ph}) ; 8.30\left(\mathrm{~d}, 2 \mathrm{H},{ }^{3} J_{\mathrm{HH}}=7.9 \mathrm{~Hz}, 5,15-o 2-\mathrm{Ph}\right) ; 8.17-8.15\left(\mathrm{~d}, 3 \mathrm{H},{ }^{3} J_{\mathrm{HH}}=8.1 \mathrm{~Hz}, 5,15-m 1 \& 10-m 1-\right.$ $\mathrm{Ph}$, overlapping); $8.13\left(\mathrm{~d}, 1 \mathrm{H},{ }^{3} J_{\mathrm{HH}}=7.9 \mathrm{~Hz}, 10-o 2-\mathrm{Ph}\right) ; 8.08\left(\mathrm{~d}, 2 \mathrm{H},{ }^{3} J_{\mathrm{HH}}=8.1 \mathrm{~Hz}, 5,15-m 2-\right.$ $\mathrm{Ph}) ; 8.03\left(\mathrm{~d}, 1 \mathrm{H},{ }^{3} \mathrm{~J}_{\mathrm{HH}}=8 \mathrm{~Hz}, 10-m 2-\mathrm{Ph}\right)$. Elemental analysis: Found: C 56.54, H 2.61, N 8.10; calcd: C 57.01, H 2.39, N 8.31. MS (ESI): $\mathrm{M}^{+}=843.06$ (expt), 842.68 (calcd for $\left.\mathrm{C}_{40} \mathrm{H}_{20} \mathrm{~F}_{9} \mathrm{~N}_{5} \mathrm{Ru}\right)$.

$\mathbf{R u}[\mathbf{T P C}](\mathbf{N})$. Yield $12.69 \mathrm{mg}(14.62 \%)$. UV-vis $\left(\mathrm{CH}_{2} \mathrm{Cl}_{2}\right): \lambda_{\max }(\mathrm{nm}),\left[\varepsilon \times 10^{-4}\left(\mathrm{M}^{-1} \mathrm{~cm}^{-}\right.\right.$ $\left.{ }^{1}\right)$ ]: 418 (9.52), 505 (1.50), 592 (1.13). ${ }^{1} \mathrm{H}$ NMR (400 MHz, -20 $\left.{ }^{\circ} \mathrm{C}\right): \delta 9.54\left(\mathrm{~d}, 2 \mathrm{H},{ }^{3} \mathrm{~J}_{\mathrm{HH}}=4.4 \mathrm{~Hz}\right.$, $\beta-\mathrm{H}) ; 9.28\left(\mathrm{~d}, 2 \mathrm{H},{ }^{3} J_{\mathrm{HH}}=4.9 \mathrm{~Hz}, \beta-\mathrm{H}\right) ; 9.16\left(\mathrm{~d}, 2 \mathrm{H},{ }^{3} J_{\mathrm{HH}}=4.4 \mathrm{~Hz}, \beta-\mathrm{H}\right) ; 9.03\left(\mathrm{~d}, 2 \mathrm{H},{ }^{3} J_{\mathrm{HH}}=4.8\right.$ $\mathrm{Hz}, \beta-\mathrm{H}) ; 8.52\left(\mathrm{~d}, 2 \mathrm{H},{ }^{3} J_{\mathrm{HH}}=8.1 \mathrm{~Hz}, 5,15-o 1-\mathrm{Ph}\right) ; 8.44\left(\mathrm{~d}, 1 \mathrm{H},{ }^{3} J_{\mathrm{HH}}=7.9 \mathrm{~Hz}, 10-o 1-\mathrm{Ph}\right) ; 8.17$ $\left(\mathrm{d}, 2 \mathrm{H},{ }^{3} J_{\mathrm{HH}}=8.1 \mathrm{~Hz}, 5,15-o 2-\mathrm{Ph}\right) ; 8.01\left(\mathrm{~d}, 1 \mathrm{H},{ }^{3} J_{\mathrm{HH}}=7.8 \mathrm{~Hz}, 10-o 2-\mathrm{Ph}\right) ; 7.92-7.72(\mathrm{~m}, 9 \mathrm{H}$, 5,15- $m 1 \& m 2-\mathrm{Ph}, 10-m 1 \& m 2,5,10,15-p$-Ph overlapping). Elemental analysis: Found: C 68.29, H 3.64, N 10.66; calcd: C 69.58, H 3.63, N 10.97. MS (ESI): M $^{+}=639.10$ (expt), 638.68 (calcd for $\mathrm{C}_{37} \mathrm{H}_{23} \mathrm{~N}_{5} \mathrm{Ru}$ ).

$\mathbf{R u}\left[\mathbf{T p} \mathbf{C H} \mathbf{H}_{3} \mathbf{P C}\right](\mathbf{N})$. Yield $17.26 \mathrm{mg}(18.65 \%)$. UV-vis $\left(\mathrm{CH}_{2} \mathrm{Cl}_{2}\right): \lambda_{\max }(\mathrm{nm}),\left[\varepsilon \times 10^{-4}\left(\mathrm{M}^{-}\right.\right.$ $\left.{ }^{1} \mathrm{~cm}^{-1}\right)$ ]: 418 (8.64), 508 (1.53), $\left.592(1.12) .{ }^{1} \mathrm{H} \mathrm{NMR} \mathrm{(400} \mathrm{MHz,}-20^{\circ} \mathrm{C}\right): \delta 9.56\left(\mathrm{~d}, 2 \mathrm{H},{ }^{3} J_{\mathrm{HH}}=\right.$ $4.4 \mathrm{~Hz}, \beta-\mathrm{H}) ; 9.30\left(\mathrm{~d}, 2 \mathrm{H},{ }^{3} J_{\mathrm{HH}}=4.8 \mathrm{~Hz}, \beta-\mathrm{H}\right) ; 9.18\left(\mathrm{~d}, 2 \mathrm{H},{ }^{3} J_{\mathrm{HH}}=4.4 \mathrm{~Hz}, \beta-\mathrm{H}\right) ; 9.05(\mathrm{~d}, 2 \mathrm{H}$, $\left.{ }^{3} J_{\mathrm{HH}}=4.8 \mathrm{~Hz}, \beta-\mathrm{H}\right) ; 8.42\left(\mathrm{~d}, 2 \mathrm{H},{ }^{3} J_{\mathrm{HH}}=7.7 \mathrm{~Hz}, 5,15-o 1-\mathrm{Ph}\right) ; 8.33\left(\mathrm{~d}, 1 \mathrm{H},{ }^{3} J_{\mathrm{HH}}=7.9 \mathrm{~Hz}, 10-o 1-\right.$ $\mathrm{Ph}) ; 8.08\left(\mathrm{~d}, 2 \mathrm{H},{ }^{3} J_{\mathrm{HH}}=7.9 \mathrm{~Hz}, 5,15-o 2-\mathrm{Ph}\right) ; 7.91\left(\mathrm{~d}, 1 \mathrm{H},{ }^{3} J_{\mathrm{HH}}=8.4 \mathrm{~Hz}, 10-o 2-\mathrm{Ph}\right) ; 7.73(\mathrm{~d}, 2 \mathrm{H}$, $\left.{ }^{3} J_{\mathrm{HH}}=8 \mathrm{~Hz}, 5,15-m 1-\mathrm{Ph}\right) ; 7.68\left(\mathrm{~d}, 1 \mathrm{H},{ }^{3} J_{\mathrm{HH}}=8.5 \mathrm{~Hz}, 10-m 1-\mathrm{Ph}\right) ; 7.65\left(\mathrm{~d}, 2 \mathrm{H},{ }^{3} J_{\mathrm{HH}}=7.7 \mathrm{~Hz}\right.$, 5,15-m2-Ph); 7.58 (d, 1H, $\left.{ }^{3} J=8.5 \mathrm{~Hz}, 10-m 2-\mathrm{Ph}\right) ; 2.71$ (s, 6H, 10-p- $\left.\mathrm{CH}_{3}\right) ; 2.70$ (s, 3H, 10-p$\mathrm{CH}_{3}$ ). Elemental analysis: Found: C 70.38, H 4.34, N 10.22; calcd: C 70.57, H 4.29, N 10.29. MS (ESI): $\mathrm{M}^{+}=681.14$ (expt), 680.76 (calcd for $\left.\mathrm{C}_{40} \mathrm{H}_{29} \mathrm{~N}_{5} \mathrm{Ru}\right)$.

Ru[TpOMePC](N). Yield $11.13 \mathrm{mg}(11.41 \%)$. UV-vis $\left(\mathrm{CH}_{2} \mathrm{Cl}_{2}\right): \lambda_{\max }(\mathrm{nm}),\left[\varepsilon \times 10^{-4}\right.$ $\left(\mathrm{M}^{-1} \mathrm{~cm}^{-1}\right)$ ]: 419 (8.75), $510(1.57), 592(1.11) .{ }^{1} \mathrm{H}$ NMR $\left(400 \mathrm{MHz},-20^{\circ} \mathrm{C}\right): \delta 9.48\left(\mathrm{~d}, 2 \mathrm{H},{ }^{3} J_{\mathrm{HH}}\right.$ $=4.4 \mathrm{~Hz}, \beta-\mathrm{H}) ; 9.27\left(\mathrm{~d}, 2 \mathrm{H},{ }^{3} J_{\mathrm{HH}}=4.8 \mathrm{~Hz}, \beta-\mathrm{H}\right) ; 9.12\left(\mathrm{~d}, 2 \mathrm{H},{ }^{3} J_{\mathrm{HH}}=4.9 \mathrm{~Hz}, \beta-\mathrm{H}\right) ; 9.02(\mathrm{~d}, 2 \mathrm{H}$, $\left.{ }^{3} J_{\mathrm{HH}}=4.9 \mathrm{~Hz}, \beta-\mathrm{H}\right) ; 8.40\left(\mathrm{~d}, 2 \mathrm{H},{ }^{3} J_{\mathrm{HH}}=8.3 \mathrm{~Hz}, 5,15-o 1-\mathrm{Ph}\right) ; 8.30\left(\mathrm{~d}, 1 \mathrm{H},{ }^{3} J_{\mathrm{HH}}=8.3 \mathrm{~Hz}, 10-o 1-\right.$ $\mathrm{Ph}) ; 8.06\left(\mathrm{~d}, 2 \mathrm{H},{ }^{3} J_{\mathrm{HH}}=8.3 \mathrm{~Hz}, 5,15-o 2-\mathrm{Ph}\right) ; 7.89\left(\mathrm{~d}, 1 \mathrm{H},{ }^{3} J_{\mathrm{HH}}=8.1 \mathrm{~Hz}, 10-o 2-\mathrm{Ph}\right) ; 7.40(\mathrm{~d}, 2 \mathrm{H}$, $\left.{ }^{3} J_{\mathrm{HH}}=8.4 \mathrm{~Hz}, 5,15-m 1-\mathrm{Ph}\right) ; 7.39\left(\mathrm{~d}, 1 \mathrm{H},{ }^{3} J_{\mathrm{HH}}=8.4 \mathrm{~Hz}, 10-m 1-\mathrm{Ph}\right) ; 7.33\left(\mathrm{~d}, 2 \mathrm{H},{ }^{3} J_{\mathrm{HH}}=8.4 \mathrm{~Hz}\right.$, 5,15-m2-Ph); $7.25\left(\mathrm{~d}, 1 \mathrm{H},{ }^{3} J_{\mathrm{HH}}=8 \mathrm{~Hz}, 10-m 2-\mathrm{Ph}\right) ; 4.04$ (s, 6H, 5, 15-p-OCH $) ; 4.03$ (s, 3H, 10- $p$ $\mathrm{OCH}_{3}$ ). Elemental analysis: Found: C 64.25, H 4.20, N 9.05; calcd: C 65.92, H 4.01, N 9.61. MS (ESI): $\mathrm{M}^{+}=729.13$ (expt), 728.76 (calcd for $\mathrm{C}_{40} \mathrm{H}_{29} \mathrm{O}_{3} \mathrm{~N}_{5} \mathrm{Ru}$ ). 
X-ray structure determinations. X-ray data for $\mathrm{Ru}^{\mathrm{VI}}[\mathrm{TPC}](\mathrm{N}), \mathrm{Ru}\left[\mathrm{T} p \mathrm{CF}_{3} \mathrm{PC}\right](\mathrm{N})$, and $\left\{\mathrm{Ru}\left[\mathrm{T} p \mathrm{CF}_{3} \mathrm{PC}\right]\right\}_{2}$ were collected on beamline 11.3.1 at the Advanced Light Source, Lawrence Berkeley National Lab. Samples were mounted on MiTeGen ${ }^{\circledR}$ kapton loops and placed in a 100(2) K nitrogen cold stream provided by an Oxford Cryostream 800 Plus low temperature apparatus on the goniometer head of a Bruker D8 diffractometer equipped with a PHOTON100 CMOS detector operating in shutterless mode. Diffraction data were collected for synchrotron radiation monochromated with silicon(111) to a wavelength of $0.7749(1) \AA$. An approximate fullsphere of data was collected using a combination of phi and omega scans with scan speeds of 1 second per degree for the phi scans, and 1 and 3 seconds per degree for the omega scans at $2 \theta=$ 0 and -45 , respectively. The structures were solved by intrinsic phasing (SHELXT) ${ }^{50}$ and refined by full-matrix least squares on $F^{2}$ (SHELXL-2014). ${ }^{51}$ All non-hydrogen atoms were refined anisotropically. Hydrogen atoms were geometrically calculated and refined as riding atoms. Additional crystallographic information has been summarized in Table 1 and full details can be found in the crystallographic information files provided in the Supplementary Information.

Computational methods. All ground-state and time-dependent DFT calculations were carried with ADF 2014 program system with B3LYP exchange-correlation functional and the D3 dispersion correction. ${ }^{52,53}$ For the experimentally studied molecules M[TPC](NO) and $\mathrm{M}[\mathrm{TPC}](\mathrm{N})(\mathrm{M}=\mathrm{Ru}, \mathrm{Os})$, we used the relativistic ZORA Hamiltonian applied as a scalar correction, ZORA Slater-type TZ2P basis sets, and the COSMO model for solvation (solvent = dichloromethane). For the truncated models $\mathrm{M}[\mathrm{Cor}](\mathrm{N})(\mathrm{M}=\mathrm{Ru}, \mathrm{Os}$, Cor $=$ unsubstituted corrole), TDDFT (COSMO) calculations were carried out with ZORA-STO-TZP basis sets and the ZORA Hamiltonian applied both as a scalar correction and with spin-orbit coupling. A third set of calculations were carried out on these compounds with the same basis set but with a nonrelativistic Hamiltonian.

Acknowledgements. This work was supported by grants 231086 and 262229 of the Research Council of Norway and by the Advanced Light Source, Berkeley, California. The Advanced Light Source is supported by the Director, Office of Science, Office of Basic Energy Sciences, of the U.S. Department of Energy under Contract No. DE-AC02-05CH11231. 


\section{References}

${ }^{1}$ Early review: Guilard, R.; Barbe, J.-M.; Stern, C.; Kadish, K. M. The Porphyrin Handbook; Kadish, K. M.; Smith, K. M.; Guilard, R., Eds.; Elsevier Science: San Diego, 2003; Vol. 18; pp 303-349.

${ }^{2}$ Orlowski, R.; Gryko, D. T. Chem. Rev. 2017, 117, 3102-3137.

${ }^{3}$ Thomas, K. E.; Alemayehu, A. B.; Conradie, J.; Beavers, C. M.; Ghosh, A. The Structural Chemistry of Metallocorroles: Combined X-Ray Crystallography and Quantum Chemistry Studies Afford Unique Insights. Acc. Chem. Res. 2012, 45, 1203-1214.

${ }^{4}$ Ghosh, A. Chem. Rev. Electronic Structure of Corrole Derivatives: Insights from Molecular Structures, Spectroscopy, Electrochemistry, and Quantum Chemical Calculations. Chem. Rev. 2017, 117, 3798-3881.

${ }^{5}$ Teo, R. D.; Hwang, J. Y.; Termini, J.; Gross, Z.; Gray, H. B. Chem. Rev. 2017, 117, 27112729.

${ }^{6}$ Che, C.-M.; Lo, V. K.-Y.; Zhou, C-Y.; Huang, J.-S. Selective Functionalisation of Saturated CH bonds with Metalloporphyrin Catalysts. Chem. Soc. Rev. 2011, 40, 1950-1975.

${ }^{7}$ Ethirajan, M.; Chen, Y.; Joshi, P.; Pandey, R. K. The Role of Porphyrin Chemistry in Tumor Imaging and Photodynamic Therapy. Chem. Soc. Rev. 2011, 40, 340-362.

${ }^{8}$ Buckley, H. L.; Arnold, J. Recent Developments in Out-of-Plane Metallocorrole Chemistry Across the Periodic Table. Dalton Trans. 2015, 44, 30-36.

${ }^{9}$ Palmer, J. H.; Durrell, A. C.; Gross, Z.; Winkler, J. R.; Gray, H. B. Near-IR Phosphorescence of Iridium(III) Corroles at Ambient Temperature. J. Am. Chem. Soc. 2010, 132, 9230-9231. ${ }^{10}$ Borisov, S. M.; Alemayehu, A.; Ghosh, A. Osmium-Nitrido Corroles as NIR Indicators for Oxygen Sensors and Triplet Sensitizers for Organic Upconversion and Singlet Oxygen Generation. J. Mater. Chem. C 2016, 4, 5822-5828.

${ }^{11}$ Alemayehu, A. B.; Day, N. U.; Mani, T.; Rudine, A. B.; Thomas, K. E.; Gederaas, O. A.; Vinogradov, S. A.; Wamser, C. C.; Ghosh, A. Gold Tris(carboxyphenyl)corroles as Multifunctional Materials: Room Temperature Near-IR Phosphorescence and Applications to Photodynamic Therapy and Dye-Sensitized Solar Cells. ACS Appl. Mater. Interfaces 2016, 8, 18935-18942. 
${ }^{12}$ Simkhovich, L.; Luobeznova, I.; Goldberg, I.; Gross, Z. Mono- and Binuclear Ruthenium Corroles: Synthesis, Spectroscopy, Electrochemistry, and Structural Characterization. Chem. Eur. J. 2003, 9, 201-208.

${ }^{13}$ Mingos, D. M. P. Historical Introduction to Nitrosyl Complexes. Struct. Bond. 2014, 153, 144.

${ }^{14}$ Pyykkö, P. Relativistic Effects in Chemistry: More Common Than You Thought. Annu. Rev. Phys. Chem. 2012, 63, 45-64.

${ }^{15}$ Palmer, J. H.; Durrell, A. C.; Gross, Z.; Winkler, J. R.; Gray, H. B. Iridium Corroles. J. Am. Chem. Soc. 2008, 130, 7786-7787.

${ }^{16}$ Alemayehu, A. B.; Ghosh, A. Gold Corroles. J. Porphyrins Phthalocyanines 2011, 15, 106110.

${ }^{17}$ Rabinovitch, E.; Goldberg, I.; Gross, Z. Gold(I) and Gold(III) Corroles. Chem. Eur. J. 2011, 17, 12294-12301.

${ }^{18}$ Thomas, K. E.; Alemayehu, A. B.; Conradie, J.; Beavers, C.; Ghosh, A. Synthesis and Molecular Structure of Gold Triarylcorroles. Inorg. Chem. 2011, 50, 12844-12851.

${ }^{19}$ Alemayehu, A. B.; Vazquez-Lima, H.; Beavers, C. M.; Gagnon, K. J.; Bendix, J.; Ghosh, A. Platinum Corroles. Chem. Comm. 2014, 50, 11093-11096.

${ }^{20}$ Brothers, P. J.; Collman, J. P. The Organometallic Chemistry of Transition-Metal Porphyrin Complexes. Acc. Chem. Res. 1986, 19, 209-215.

${ }^{21}$ Collman, J. P.; Arnold, H. J. Multiple Metal-Metal Bonds in 4d and 5d Metal-Porphyrin Dimers. Acc. Chem. Res. 1993, 26, 586-592.

${ }^{22}$ Jérôme, F.; Billier, B.; Barbe, J.-M.; Espinosa, E.; Dahaoui, S.; Lecomte, C.; Guilard, R. Evidence for the Formation of a $\mathrm{Ru}^{\mathrm{III}}-\mathrm{Ru}^{\mathrm{III}}$ Bond in a Ruthenium Corrole Homodimer. Angew. Chem. Int. Ed. 2000, 39, 4051-4053.

${ }^{23}$ Kadish, K. M.; Burdet, F.; Jerome, F.; Barbe, J.-M.; Ou, Z.; Shao, J.; Guilard, R. Synthesis, Physicochemical and Electrochemical Properties of Metal-Metal Bonded Ruthenium Corrole Homodimers. J. Organomet. Chem. 2002, 652, 69-76.

${ }^{24}$ Alemayehu, A. B.; Gagnon, K. J.; Terner, J.; Ghosh, A. Oxidative Metalation as a Route to Size-Mismatched Macrocyclic Complexes: Osmium Corroles. Angew. Chem. Int. Ed. 2014, 53, 14411-14414. 
${ }^{25}$ Gladwin, M. T.; Grubina, R.; Doyle, M. P. The New Chemical Biology of Nitrite Reactions with Hemoglobin: R-State Catalysis, Oxidative Denitrosylation, and Nitrite Reductase/Anhydrase. Acc. Chem. Res. 2009, 42, 157-167.

${ }^{26}$ Heinecke, J.; Ford, P. C. Mechanistic studies of nitrite reactions with metalloproteins and models relevant to mammalian physiology. Coord. Chem. Rev. 2010, 254, 235-247.

${ }^{27}$ Chatterjee, D.; Shome, S.; Jaiswal, N.; Banerjee, P. Nitrite reduction mediated by the complex $\mathrm{Ru}^{\mathrm{III}}$ (EDTA). Dalton Trans. 2014, 43, 13596-13600.

${ }^{28}$ Odom, A. L.; Cummins, C. C.; Protasiewicz, J. D. Nitric Oxide Cleavage: Synthesis of Terminal Chromium(VI) Nitrido Complexes via Nitrosyl Deoxygenation. J. Am. Chem. Soc. 1995, 117, 6613-6614.

${ }^{29}$ Garcia, M. E.; Garcia-Vivo, D.; Melon, S.; Ruiz, M. A.; Graiff, C.; Tiripicchio, A. LowTemperature $\mathrm{N}-\mathrm{O}$ Bond Cleavage in Nitrosyl Ligands Induced by the Unsaturated Dimolybdenum Anion $\left[\mathrm{Mo}_{2}\left(\eta^{5}-\mathrm{C}_{5} \mathrm{H}_{5}\right)_{2}\left(\mu-\mathrm{PPh}_{2}\right)(\mu-\mathrm{CO})_{2}\right]^{-}$. Inorg. Chem. 2009, 48, 9282-9293. ${ }^{30}$ Mingos, D. M. P. Ambivalent Lewis Acid/Bases with Symmetry Signatures and Isolobal Analogies. Struct. Bond. 2014, 154, 1-52.

${ }^{31}$ Ghosh, A. Metalloporphyrin-NO Bonding: Building Bridges with Organometallic Chemistry. Acc. Chem. Res. 2005, 38, 943-954.

${ }^{32}$ Vazquez-Lima, H.; Norheim, H. K.; Einrem, R. F.; Ghosh, A. Cryptic Noninnocence: FeNO Corroles in a New Light. Dalton Trans. 2015, 44, 10146-10151.

${ }^{33}$ Norheim, H.-K.; Capar, J.; Einrem, R. F.; Gagnon, K. J.; Beavers, C. M.; Vazquez-Lima, H.; Ghosh, A. Ligand Noninnocence in FeNO Corroles: Insights from $\beta$-Octabromocorrole Complexes. Dalton Trans. 2016, 45, 681-689.

34 The superscript 6 or 7 refers to the Enemark-Feltham electron count (the effective number of metal d electrons in a nitrosyl complex): Enemark, J. H.; Feltham, R. D. Principles of Structure, Bonding and Reactivity for Metal Nitrosyl Complexes. Coord. Chem. Rev. 1974, 13, 339-406. ${ }^{35}$ Zakharieva, O.; Schünemann, V.; Gerdan, M.; Licoccia, S.; Cai, S.; Walker, F. A.; Trautwein, A. X. Is the Corrolate Macrocycle Innocent or Noninnocent? Magnetic Susceptibility, Mössbauer, ${ }^{1} \mathrm{H}$ NMR, and DFT Investigations of Chloro- and Phenyliron Corrolates. J. Am. Chem. Soc 2002, 124, 6636-6648.

${ }^{36}$ Walker, F. A.; Licoccia, S.; Paolesse, R. Iron Corrolates: Unambiguous Chloroiron(III)

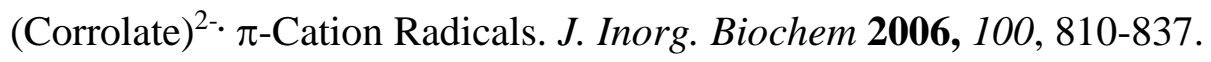


${ }^{37}$ Yi, G.-B.; Khan, M. A.; Richter-Addo, G. B. Ruthenium Porphyrins Containing Nitrosyl, Nitrosamine, Thiolate, and Amine Ligands. Inorg. Chem. 1996, 35, 3453-3454.

${ }^{38}$ Kadish, K. M.; Adamian, V. A.; van Caemelbecke, E.; Tan, Z.; Tagliatesta, P.; Bianco, P.;

Boschi, T.; Yi, G.-B.; Khan, M. A.; Richter-Addo, G. B. Synthesis, Characterization, and Electrochemistry of Ruthenium Porphyrins Containing a Nitrosyl Axial Ligand. Inorg. Chem. 1996, 35, 1343-1348.

${ }^{39}$ Miranda, K. M.; Bu, X.; Lorkovic, I.; Ford, P. C. Synthesis and Structural Characterization of Several Ruthenium Porphyrin Nitrosyl Complexes. Inorg. Chem. 1997, 36, 4838-4848.

${ }^{40}$ Wasbotten, I. H.; Wondimagegn, T.; Ghosh, A. Electronic Absorption, Resonance Raman, and Electrochemical Studies of Planar and Saddled Copper(III) Meso-Triarylcorroles. Highly Substituent-Sensitive Soret Bands as a Distinctive Feature of High-Valent Transition Metal Corroles. J. Am. Chem. Soc. 2002, 124, 8104-8116.

${ }^{41}$ Thomas, K. E.; Wasbotten, I. H.; Ghosh, A. Copper $\beta$-Octakis(Trifluoromethyl)Corroles: New Paradigms for Ligand Substituent Effects in Transition Metal Complexes. Inorg. Chem. 2008, 47, 10469-10478.

${ }^{42}$ Berg, S.; Thomas, K. E.; Beavers, C. M.; Ghosh, A. Undecaphenylcorroles. Inorg. Chem. 2012, 51, 9911-9916.

${ }^{43}$ Thomas, K. E.; Vazquez-Lima, H.; Fang, Y.; Song, Y.; Gagnon, K. J.; Beavers, C. M.; Kadish, K. M.; Ghosh, A. Ligand Noninnocence in Coinage Metal Corroles: A Silver Knife-Edge. Chem. - Eur. J. 2015, 21, 16839-16847.

${ }^{44}$ Steene, E.; Wondimagegn, T.; Ghosh, A. Electrochemical and Electronic Absorption Spectroscopic Studies of Substituent Effects in Iron(IV) and Manganese(IV) Corroles. Do the Compounds Feature High-Valent Metal Centers or Noninnocent Corrole Ligands? Implications for Peroxidase Compound I and II Intermediates. J. Phys. Chem. B 2001, 105, 11406-11413. Addition/correction: J. Phys. Chem. B 2002, 106, 5312-5312.

${ }^{45}$ Thomas, K. E.; Vazquez-Lima, H.; Fang, Y.; Song, Y.; Gagnon, K. J.; Beavers, C. M.; Kadish, K. M.; Ghosh, A. Ligand Noninnocence in Coinage Metal Corroles: A Silver Knife-Edge. Chem. - Eur. J. 2015, 21, 16839-16847.

${ }^{46}$ Ganguly, S.;Vazquez-Lima, H.; Ghosh, A. Wolves in Sheep's Clothing: $\mu$-Oxo-Diiron Corroles Revisited. Chem. Eur. J. 2016, 22, 10336-10340. 
${ }^{47}$ Johansen, I.; Norheim, H.-K.; Larsen, S.; Alemayehu, A. B.; Conradie, J.; Ghosh, A. Substituent Effects on Metallocorrole Spectra: Insights from Chromium-Oxo and MolybdenumOxo Triarylcorroles. J. Porphyrins Phthalocyanines 2011, 15, 1335-1344.

${ }^{48}$ Einrem, R. F.; Braband, H.; Fox, T.; Vazquez-Lima, H.; Alberto, R.; Ghosh, A. Synthesis and molecular structure of ${ }^{99} \mathrm{Tc}$ Corroles. Chem. Eur. J. 2016, 22, 18747-18751.

${ }^{49}$ Einrem, R. F.; Gagnon, K. J.; Alemayehu, A. B.; Ghosh, A. Metal-Ligand Misfits: Facile Access to Rhenium-Oxo Corroles by Oxidative Metalation. Chem. Eur. J. 2016, 22, 517-520. ${ }^{50}$ Sheldrick, G. M. SHELXT - Integrated Space-Group and Crystal-Structure Determination. Acta Cryst. 2015, A71, 3-8.

${ }^{51}$ Sheldrick, G. M. Crystal Structure Refinement with SHELXL. Acta Cryst. 2015, C71, 3-8. ${ }^{52}$ The ADF program system uses methods described in: Velde, G. T.; Bickelhaupt, F. M.; Baerends, E. J.; Guerra, C. F.; van Gisbergen, S. J. A.; Snijders, J. G.; Ziegler, T. J. Comput. Chem. 2001, 22, 931-967.

${ }^{53}$ For additional details on all aspects of the calculations, see the ADF program manual: http://www.scm.com/ADF/. 
For Table of Contents only:

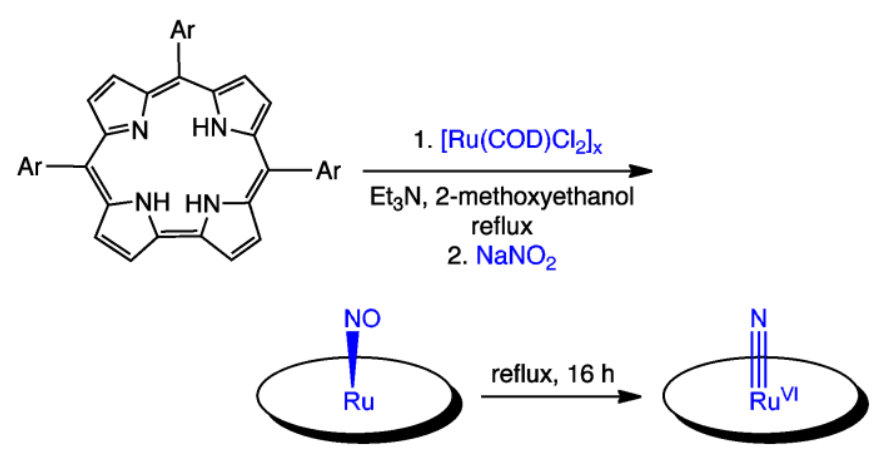

Synopsis: Exposure of free-base meso-triarylcorroles and $\left[\mathrm{Ru}(\mathrm{COD}) \mathrm{Cl}_{2}\right]_{\mathrm{x}}$ in refluxing 2-

methoxyethanol to nitrite leads to RuNO corroles in seconds and subsequently, via a second deoxygenation over some $16 \mathrm{~h}$, to $\mathrm{Ru}^{\mathrm{VI}} \mathrm{N}$ corroles. 